\title{
Opposing effects of monomeric and pentameric C-reactive protein on endothelial progenitor cells
}

\author{
I. Ahrens $\cdot$ H. Domeij $\cdot$ S. U. Eisenhardt $\cdot$ D. Topcic $\cdot$ \\ M. Albrecht $\cdot$ E. Leitner $\cdot$ K. Viitaniemi - J. B. Jowett \\ M. Lappas $\cdot$ C. Bode $\cdot$ I. Haviv $\cdot$ K. Peter
}

Received: 21 September 2010/Revised: 12 April 2011/Accepted: 29 April 2011/Published online: 12 May 2011

(C) Springer-Verlag 2011

\begin{abstract}
C-reactive protein (CRP) has been linked to the pathogenesis of atherosclerosis. The dissociation of native, pentameric (p)CRP to monomeric (m)CRP on the cell membrane of activated platelets has recently been demonstrated. The dissociation of pCRP to mCRP may explain local pro-inflammatory reactions at the site of developing atherosclerotic plaques. As a biomarker, pCRP predicts cardiovascular adverse events and so do reduced levels and function of circulating endothelial progenitor cells (EPCs). We hypothesised that $\mathrm{mCRP}$ and $\mathrm{pCRP}$ exert a differential effect on EPC function and differentiation. EPCs were treated with
\end{abstract}

Ahrens and Domeij have contributed equally to this work.

Electronic supplementary material The online version of this article (doi:10.1007/s00395-011-0191-y) contains supplementary material, which is available to authorized users.

I. Ahrens $(\varangle) \cdot$ M. Albrecht $\cdot$ C. Bode

Department of Cardiology and Angiology, University Hospital Freiburg, Hugstetter Street 55, 79106 Freiburg, Germany

e-mail: ingo.ahrens@uniklinik-freiburg.de

I. Ahrens · H. Domeij - D. Topcic - M. Albrecht - E. Leitner ·

K. Viitaniemi · K. Peter

Atherothrombosis and Vascular Biology, Baker IDI Heart

and Diabetes Institute, Melbourne, Australia

S. U. Eisenhardt

Department of Plastic and Hand Surgery, University Hospital Freiburg, Freiburg, Germany

J. B. Jowett · I. Haviv

The Blood and DNA Profiling Facility,

Baker IDI Heart and Diabetes Institute, Melbourne, Australia

M. Lappas

Department of Obstetrics and Gynaecology, Mercy Hospital

for Women, University of Melbourne, Melbourne, Australia
mCRP or pCRP for $72 \mathrm{~h}$, respectively. Phenotypical characterisation was done by flow cytometry and immunofluorescence microscopy, while the effect of mCRP and pCRP on gene expression was examined by whole-genome gene expression analysis. The functional capacity of EPCs was determined by colony forming unit (CFU) assay and endothelial tube formation assay. Double staining for acetylated LDL and ulex lectin significantly decreased in cells treated with pCRP. The length of tubuli in a matrigel assay with HUVECs decreased significantly in response to pCRP, but not to mCRP. The number of CFUs increased after pCRP treatment. RNA expression profiling demonstrated that $\mathrm{mCRP}$ and pCRP cause highly contradictory gene regulation. Interferon-responsive genes (IFI44L, IFI44, IFI27, IFI 6, MX1, OAS2) were among the highly up-regulated genes after mCRP, but not after pCRP treatment. In conclusion, EPC phenotype, genotype and function were differentially affected by mCRP and pCRP, strongly arguing for differential roles of these two CRP conformations. The up-regulation of interferon-inducible genes in response to mCRP may constitute a mechanism for the local regulation of EPC function.

Keywords CRP - mCRP - EPC - Cardiovascular disease Gene array $\cdot$ Interferon-alpha

\section{Introduction}

C-reactive protein (CRP) is an acute phase protein that consists of five non-covalently linked subunits forming a disc-shaped pentamer (pCRP) with a molecular weight of $115 \mathrm{kDa}$. The serum level of pCRP has been established as an independent risk factor for cardiovascular events [23, $51,71]$. We recently demonstrated the dissociation of pCRP to monomeric $(\mathrm{m}) \mathrm{CRP}$ on the cell membrane of 
activated platelets and the deposition of mCRP in atherosclerotic plaques, thereby suggesting a causal link between localised inflammation, C-reactive protein and atherosclerosis $[15,17]$. In addition to our recent findings, evidence from other studies points towards a differential effect of mCRP and pCRP on the activation of platelets and leukocytes $[16,34,40]$, which are known key players involved in the initiation of atherosclerotic plaque development [26].

While elevated serum levels of C-reactive protein are predictive of adverse cardiovascular events [23, 51, 71], decreased numbers of circulating endothelial progenitor cells (EPCs) and impaired function of EPCs have been described [18, 31, 45, 48, 55, 67, 68], thereby generating the hypothesis that $\mathrm{C}$-reactive protein might have a negative effect on EPC number and function. In addition, in vitro experiments have shown that pCRP reduces the number of differentiated EPCs along with a reduction in EPC-mediated endothelial tube formation [64]. Furthermore, a recent study by the same group demonstrated a dose-dependent increase in pCRP-induced formation of reactive oxygen species and apoptosis in EPCs [19].

However, the effects of C-reactive protein are versatile and still not fully understood. It appears that inflammation accompanied by elevated levels of C-reactive protein in general does not necessarily lead to decreased levels of circulating EPCs [20, 47]. In fact, the EPC number may even be elevated [20].

The recent description of the dissociation of pCRP to mCRP on cell membranes thereby generating two biologically distinct conformations of C-reactive protein [15, 28] prompted us to examine whether mCRP and pCRP have a differential effect on EPC differentiation and function.

The term EPC has initially been applied to describe a cell population possessing the ability to regenerate damaged endothelium and contribute to the development of new vessel structures (EPC) [3]. Investigations into the different purification and culturing methods have sparked an ongoing discussion about a more differentiated definition of these progenitor cells with regenerative capacities $[13,24,50,53,58,61,62,69]$. The new definition allows a crude separation into early outgrowth EPC or pro-angiogenic cells [13] and endothelial outgrowth cells (EOCs) also described as endothelial colony forming cells (ECFCs) $[24,61,69]$. The cells that were used in the current study were derived from $\mathrm{CD} 34^{+}$selected human umbilical cord blood mononuclear cells. After in vitro expansion, the cells were differentiated into early outgrowth EPCs [1]. CD34 is a hematopoietic progenitor cell (HPC) marker, which has been linked to the term EPC throughout the majority of the available EPC literature [63, 66]. Therefore, for simplification purposes we use the term HPC to describe the $\mathrm{CD} 34^{+}$-purified cells and the general term EPC to describe the cells that were used for the experiments throughout our study.

CD $34^{+}$cells purified by positive selection from human cord blood samples were expanded in vitro and thereafter differentiated into EPCs in the presence or absence of mCRP or pCRP, respectively. pCRP and mCRP showed differential effects on survival, differentiation and function of EPCs. In addition, whole-genome gene expression analysis revealed a highly differentially and opposing gene expression pattern in response to treatment with the two isoforms of CRP. Interferon-responsive genes (IFI44L, IFI44, IFI27, IFI 6, MX1, OAS2) were among the highly up-regulated genes in response to mCRP, but not pCRP treatment of EPCs.

\section{Materials and methods}

Isolation and expansion of $\mathrm{CD} 34^{+}$cells

Mononuclear cells (MNCs) were isolated from human umbilical cord blood (HUCB) obtained from healthy donors following normal full-term deliveries after their written informed consent. Ethics approval was granted by the Human Research Ethics Committee, Mercy Health, Mercy Hospital for Women, Melbourne, Australia (Project number R08/24).

HUCB was collected in $50 \mathrm{ml}$ Falcon tubes (BD Bioscience, NJ, USA) containing $15 \mathrm{ml}$ of the anticoagulant citrate phosphate dextrose. After collection, HUCB was diluted 1:3 in isolation buffer (PBS, $0.1 \%$ BSA, $0.6 \%$ citrate, $\mathrm{pH}$ 7.4). MNCs were isolated from the diluted HUCB by density gradient centrifugation, whereby $20 \mathrm{ml}$ of diluted HUCB were layered onto 15-ml Ficoll-Paque ${ }^{\mathrm{TM}}$ (GE Healthcare, Chalfont, UK) and centrifuged for $30 \mathrm{~min}$ at $800 \times g$. Thereafter, the interphase containing MNCs was collected and washed with an equal amount of isolation buffer, followed by centrifugation for $30 \mathrm{~min}$ at $500 \times g$. The washed MNCs were then subjected to magnetic beads-based selection of $\mathrm{CD} 34^{+}$cells using Dynal ${ }^{\circledR}$ CD34 Progenitor Cells Selection System (Invitrogen, Oslo, Norway) following the manufacturer's recommendation. The number of positively selected $\mathrm{CD} 34^{+}$cells, the haematopoietic progenitor cells (HPC), was assessed in a Neubauer haemocytometer and the purity $(>90 \%)$ of the $\mathrm{CD} 34^{+}$cells evaluated by flow cytometry.

The cord blood-derived CD $34^{+}$HPCs were cultured at a density of $3-5 \times 10^{4}$ cells $/ 400 \mu \mathrm{l} / 1.8 \mathrm{~cm}^{2}$ in a humidified incubator at $37^{\circ} \mathrm{C}$ with $5 \% \mathrm{CO}_{2}$. The cells were cultured for 7 days in serum-free StemSpan ${ }^{\circledR}$ medium (StemCell Technologies, Vancouver, Canada) during the initial expansion period and supplemented with $1 \%$ penicillinstreptomycin (Sigma-Aldrich, St. Louis, USA) and 
recombinant human (rh) Flt-3 ligand $(100 \mathrm{ng} / \mathrm{ml})$, rh stem cell factor $(100 \mathrm{ng} / \mathrm{ml})$, rh IL-3 $(20 \mathrm{ng} / \mathrm{ml})$ and rh IL-6 $(20 \mathrm{ng} / \mathrm{ml})$, all purchased from StemCell Technologies. Thereafter, the HPCs were cultured $\left(3 \times 10^{5}-1 \times 10^{6} \%\right.$ $1.5 \mathrm{ml} / 9.6 \mathrm{~cm}^{2}$ ) for an additional 3 days in endothelial cell growth medium-2 (EGM-2) containing FBS (2\%), hydrocortisone, hFGF, VEGF, $\mathrm{R}^{3}$-IGF-1, ascorbic acid, hEGF, gentamicin, amphotericin-B and heparin (Lonza, Basel, Siwtzerland).

Treatment of EPCs with monomeric and pentameric CRP

pCRP (Chemicon, Temecula, USA) and mCRP were prepared as described previously [15]. The expanded HPCs described above were collected and transferred to fibronectin $(10 \mu \mathrm{g} / \mathrm{ml})$ (Sigma-Aldrich)-coated plates, cultured and differentiated into EPCs for 3 days in fresh EGM-2 media in the presence or absence of mCRP $(1,5$ or $25 \mu \mathrm{g} / \mathrm{ml})$ or pCRP $(1,5$ or $25 \mu \mathrm{g} / \mathrm{ml})$, respectively. A control group of HPCs treated with EGM-2 media containing PBS (diluted 1:40) was also included.

\section{Cell viability assays}

\section{Phosphatidylserine translocation (annexin $V$ binding)}

The binding of annexin $\mathrm{V}$ to phosphatidylserine was determined using FITC-conjugated annexin V (BD Biosciences, San Jose, CA, USA). In brief, the EPCs were washed in annexin-binding buffer (10 mM HEPES, $140 \mathrm{mM} \mathrm{NaCl}, 2.5 \mathrm{mM} \mathrm{CaCl} 2, \mathrm{pH} 7.4)$ and thereafter incubated with annexin V-FITC at RT for $15 \mathrm{~min}$. After additional washing in annexin-binding buffer, the cells were analysed for annexin V-FITC binding in a FACSCalibur TM flow cytometer using CellQuest software (Becton and Dickinson, San Jose, CA, USA). Between 10,000 and 20,000 events per test were acquired. A negative control with unstained cells was included for each treatment.

\section{CytoTox-Glo ${ }^{T M}$ cytotoxicity assay}

The relative viability of EPCs treated with $\operatorname{mCRP}(1,5$, or $25 \mu \mathrm{g} / \mathrm{ml})$, pCRP $(1,5$, or $25 \mu \mathrm{g} / \mathrm{ml})$ or PBS was analysed using the CytoTox-Glo ${ }^{\mathrm{TM}}$ cytotoxicity assay (Promega, Madison, WI, USA) following the manufacturer's recommendations. In brief, EPCs were added to a 96-well luminescence plate at a concentration of 10,000 cells/well in a volume of $100 \mu \mathrm{l}$ of EGM-2. Thereafter, to detect protease activity that had been released from dead cells, $50 \mu \mathrm{l}$ of alanyl-alanyl-phenylalanyl-aminoluciferin luminogenic peptide substrate (AAF-Glo ${ }^{\mathrm{TM}}$ Substrate) mix was added to the wells and incubation was carried out for $15 \mathrm{~min}$ at RT. The plate was measured in a 96-well plate luminometer. Immediately after measurement of dead cells by luminescence, the EPCs were exposed to a lysis buffer containing digotinin for $15 \mathrm{~min}$ at RT and the luminescence was measured again. The number of viable cells was determined by subtracting the number of dead cells from the total cell count. A no-cell background control was included in the assay.

Uptake of acetylated LDL and binding of ulex lectin

To investigate the endothelial progenitor characteristics of the EPCs, binding of ulex lectin and uptake of Dil-labelled acetylated LDL (AcLDL) by the cells were analysed by dual staining of the cells at $37^{\circ} \mathrm{C}$ in PBS.

After expansion, the cells were seeded on a fibronectincoated 24-well plate with a density of $3 \times 10^{5}$ cells $/ 0.5 \mathrm{ml} /$ $1.8 \mathrm{~cm}^{2}$ and cultured in EGM-2 for 3 days in the presence or absence of mCRP, pCRP or PBS. Thereafter, cells were washed twice with PBS at $37^{\circ} \mathrm{C}$. The cells were then incubated with Dil-AcLDL $(6 \mu \mathrm{g} / \mathrm{ml})$ (Invitrogen, Carlsbad, USA) for $1 \mathrm{~h}$ at $37^{\circ} \mathrm{C}$ in the dark. Thereafter, the cells were washed twice with $\mathrm{PBS}$ at $37^{\circ} \mathrm{C}$ and incubated with FITC-conjugated ulex lectin $(10 \mu \mathrm{g} / \mathrm{ml})$ (Sigma-Aldrich, St. Louis, USA) for $1 \mathrm{~h}$ at $37^{\circ} \mathrm{C}$ in the dark. After two final washing steps with $\mathrm{PBS}$ at $37^{\circ} \mathrm{C}$, the cells were fixed with $0.3 \mathrm{ml}$ CellFIX solution (BD Biosciences, NJ, USA), and subsequently analysed for uptake of Dil-AcLDL and binding of FITC-ulex lectin using an Olympus 1X81 inverted fluorescence microscope.

The effect of mCRP and pCRP on functional characteristics of EPCs

The EPCs treated with mCRP or pCRP were studied using colony forming assay (CFU-Hill) and Matrigel $^{\mathrm{TM}}$ tube formation assay.

\section{Colony forming unit (CFU) assay}

Culture of CFU-Hill colonies (StemCell Technologies) was performed according to the manufacturer's recommendations with the exception that we used ten times less cells $\left(5 \times 10^{5}\right.$ cells/well $)$ and in vitro differentiated cord bloodderived EPCs instead of freshly prepared MNCs. In brief, after $72 \mathrm{~h}$ of culture on fibronectin in EGM-2 media in the presence or absence of mCRP or pCRP, the cells were collected and counted. The collected cells were then cultured $\left(5 \times 10^{5}\right.$ cells $\left./ 1.5 \mathrm{ml} / 9.6 \mathrm{~cm}^{-2}\right)$ on fibronectin precoated 6-well plates (BD Biosciences) in EndoCult ${ }^{\circledR}$ liquid medium containing EndoCult supplements (StemCell Technologies). After 2 days, the non-adherent cells were 
collected and transferred to fibronectin pre-coated 24-well plates (BD Biosciences) at a density of $3 \times 10^{5}$ cells $/ \mathrm{ml} /$ $1.8 \mathrm{~cm}^{2}$. After a further 3 days of culture, the cells were washed twice with PBS, fixed with methanol, and the colonies were visualised with Giemsa staining (Gibco, Carslbad, USA), following the manufacturer's recommendations. The number of colonies per well was counted with an inverted microscope (Olympus CKX41).

\section{Endothelial tube formation assay}

The capability of the mCRP- and pCRP-treated EPCs to support endothelial tube formation was assessed using Matrigel $^{\mathrm{TM}}$ (BD Biosciences) coated 96-well plates and human umbilical vein endothelial cells (HUVECs) in early passages (P3-P6). In brief, wells of a 96-well plate were coated with $50 \mu \mathrm{l}$ of ice-cold Matrigel ${ }^{\mathrm{TM}}$ followed by incubation at $37^{\circ} \mathrm{C}$ for $1 \mathrm{~h}$. Thereafter, $100 \mu \mathrm{l}$ of EGM-2 medium containing 25,000 HUVECs and $100 \mu$ of EGM-2 containing 25,000 EPCs were added to the Matrigel $^{\mathrm{TM}}$. Incubation was carried out for $16 \mathrm{~h}$ in a humidified atmosphere at $37^{\circ} \mathrm{C}$ in the presence of $5 \% \mathrm{CO}_{2}$. Tube formation was assessed with an inverted microscope (Olympus 1X81) and Cell^ $\mathrm{P}$ imaging software (Olympus). Digital photomicrographs of each single well were taken at a $4 \times$ magnification and the total number of tubes, branching points, and the length of the tubes as well as the sum of the lengths of all tubes were calculated for each well.

Whole-genome gene expression analysis of mCRP and pCRP-treated EPCs

Total RNA was extracted from $2 \times 10^{6}$ EPCs after $72 \mathrm{~h}$ of culture in EGM-2 medium in the presence or absence of mCRP $(1 \mu \mathrm{g} / \mathrm{ml})$, pCRP $(5 \mu \mathrm{g} / \mathrm{ml})$ or PBS. The RNA was obtained using Qiagen ${ }^{\circledR}$ RNeasy protect mini kit ${ }^{\mathrm{TM}}$ following the manufacturer's instructions. RNA concentration and integrity was analysed by NanoDrop (Thermo Fischer Scientific, Waltham, USA) and MultiNA microchip electrophoresis (Shimadzu Biotech, Kyoto, Japan) according to the manufacturer's recommendations. Total RNA was amplified with the TotalPrep ${ }^{\mathrm{TM}}$ RNA Amplification Kit (Ambion, UK) and applied to Illumina ${ }^{\circledR}$ Human WG-6 v3.0 Expression BeadChip kits according to the manufacturer's instructions. Fluorescent bead intensity was transformed into gene expression level via Illumina Genome Studio, including quantile normalisation [27] and background subtraction. The exported reports were analysed on GeneSpring GX10, Partek GS and arraytools (http://linus. nci.nih.gov/pub/rsimon/ ArrayTools). Genes with a raw signal $<250$ and a detection confidence $>0.8$ in at least three arrays were filtered out, leaving 6,064 genes for further analysis. Whisker box plot was used to confirm the quintile normalisation eliminated systematic cross array variations in the overall dynamic range. Quality control of the samples and controlling for systematic bias were performed using principal component analysis and unsupervised hierarchical clustering to show that samples segregated according to treatment groups. Differentially expressed genes were selected based on a Bayesian "volcano plot" of expression fold change greater than twofold and significance $p$ value of $<0.05$, including Benjamini Hochberg false discovery correction. Differential expression of the chosen genes across the treatment groups was assessed using supervised hierarchical clustering [14] that measures the proximity of distribution of samples and genes. The interpretation of the resulting gene lists was performed using gene ontology Web interface (http://david. abcc.ncifcrf.gov/), Gene Set Analysis [6], protein-protein interaction KEGG database [22] and Ingenuity Pathways Analysis [49].

\section{Quantitative real-time PCR analysis}

First-strand cDNA was synthesised using 350 ng of total RNA, obtained as described in the microarray section, and random primers in a $10 \mu \mathrm{l}$ reverse transcriptase reaction mixture using TaqMan ${ }^{\circledR}$ Reverse Transcription Reagents (Applied Biosystems) following the manufacturer's recommendations. Quantitative real-time PCR assays were carried out with Applied Biosystems 7500 real-time PCR system using SYBR ${ }^{\circledR}$ Green Mastermix (Applied Biosystems, Carlsbad, USA). Primers were designed in-house and synthesised by GeneWorks (Hindmarsh, Australia). PCR amplification was performed in a 96-well plate with a final volume of $20 \mu \mathrm{l}$ reaction mixture in each well. For each sample, $21 \mathrm{ng}$ of cDNA was loaded in duplicates with $1 \times$ SYBR $^{\circledR}$ Green Mastermix and $10 \mu \mathrm{M}$ of the following primers for: Mx1 sense 5'-CACTGCGCAGGGACCGGAA TT- $3^{\prime}$ and anti-sense $5^{\prime}$-TCCTGTAGCCTCCGACCCAGA

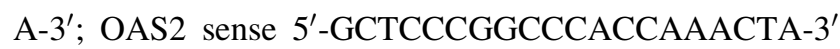
and anti-sense $5^{\prime}$-TGGGGGCAAAGACCCCTTTGG-3'; OAS3 sense $5^{\prime}$-GGACCCTGCAGTTGGGCAGT- $3^{\prime}$ and anti-sense $5^{\prime}$-CCCATGTGGGGTCAGCTGGG-3'; IFIT3 sense $5^{\prime}$-ACCGGGACCCCAGCTTTTCAG- $3^{\prime}$ and antisense 5'-AGCTGTGGAAGGATTTTCTCCAGGG-3'; IFI6 sense $5^{\prime}$-TCCGGGCTGAAGATTGCTTCTCTT- $3^{\prime}$ and anti-sense $5^{\prime}$ - ACTTTTTCTTACCTGCCTCCACCCC-3'; IFI44 sense $5^{\prime}$-GAGATGTGAGCCTGTGAGGTCCAA- $3^{\prime}$ and anti-sense 5'TTTACAGGGTCCAGCTCCCACTCA-3'; IFI27 sense $5^{\prime}$ - CCGTAGTTTTGCCCCTGGCC- ${ }^{\prime}$ and antisense $5^{\prime}$-CATGGGCACAGCCGCCATG-3'; IFI44L sense $5^{\prime}$ - ATGTGACTGGCCAAGCCGTAGT- $3^{\prime}$ and anti-sense 5'TGCCCCATCTAGCCCCATAGTGT-3'; PROK2 sense $5^{\prime}$-TGGGAGACAGCTGCCATCCAC- $3^{\prime}$ and anti-sense $5^{\prime}$-A GCCTGGCAGACATGGGCAA3'; DDIT3 sense $5^{\prime}$-TC 
AGAGCTGGAACCTGAGGAGAGA-3' and anti-sense 5'ATGGGGAGTGGCTGGAACAAGC- $3^{\prime}$. Relative expression of the genes was obtained using the differences in cycle threshold $(\mathrm{Ct})$ between the sample and $18 \mathrm{~S}$ ribosomal RNA $(\Delta \mathrm{C})$. The difference in gene expression for the treated samples compared to the PBS control samples was calculated $(\Delta \Delta \mathrm{Ct})$ and the fold difference was calculated as $2 \Delta \Delta \mathrm{Ct}$.

\section{Treatment with human IFN $\alpha 2 \mathrm{~A}$}

The expanded HPCs were collected and transferred to fibronectin $(10 \mu \mathrm{g} / \mathrm{ml})$-coated plates, cultured and differentiated into EPCs for 3 days in fresh EGM-2 media in the presence or absence of IFN $\alpha 2 \mathrm{~A}(0.1-10 \mathrm{ng} / \mathrm{ml})$ (Sigma), mCRP $(1 \mu \mathrm{g} / \mathrm{ml})$ or pCRP $(5 \mu \mathrm{g} / \mathrm{ml})$, respectively. A control group of HPCs treated with EGM-2 media containing PBS (diluted 1:40) was also included. Changes in gene expression were determined using real-time PCR. In addition, uptake of AcLDL and binding of ulex lectin, CFU assay and endothelial tube formation assay were investigated as described above.

\section{Statistical analysis}

All experiments were performed with EPCs from at least three different donors, respectively. Mean and SD were used for descriptive statistics. Statistical analysis was performed using Sigma Stat. Differences between means were assessed by analysis of variance (ANOVA) and post hoc test was carried out according to Bonferroni. $p$ values $<0.05$ were considered to be statistically significant.

\section{Results}

EPCs were treated with mCRP, pCRP or PBS for a period of $72 \mathrm{~h}$ in fibronectin-coated six-well plates $(10 \mu \mathrm{g} / \mathrm{ml})$. Thereafter EPC viability, phenotype and function were assessed. In addition, differences in gene expression profiles were assessed in EPCs derived from three different cord blood donors before and after mCRP, pCRP and PBS treatment, respectively.

\section{Assessment of mCRP and pCRP toxicity}

The effect of a 72-h treatment period of mCRP and pCRP on EPC viability was investigated using a cytotoxicity luminescence assay. First, the number of dead cells was measured and secondly the total number of cells was measured. The relative number of viable cells (relative live cell luminescence, RLU) obtained in the assay is demonstrated in Fig. 1a. There was no toxicity associated with mCRP treatment $(1,5$, or $25 \mu \mathrm{g} / \mathrm{ml}$ for
$72 \mathrm{~h})$. In fact, mCRP significantly $(p<0.05-0.001)$ increased the viability/cell numbers in a dose-dependent manner (Fig. 1a). In accordance to mCRP, pCRP at the concentrations 1 and $5 \mu \mathrm{g} / \mathrm{ml}$ for $72 \mathrm{~h}$ was not toxic to the EPCs. However, at the concentration of $25 \mu \mathrm{g} / \mathrm{ml}$, the viability of the cells was strongly reduced ( $p<0.001$, Fig. 1a). In addition to the luminescencebased cytotoxicity assay, which is based on protease activity released from cells through the loss of membrane integrity, the effect of $\mathrm{mCRP}$ and pCRP treatment on EPCs was also determined by annexin $\mathrm{V}$ binding. In accordance with the cytotoxicity assay, only pCRP at the concentration $25 \mu \mathrm{g} / \mathrm{ml}$ induced an increased binding of annexin $\mathrm{V}$, thereby indicating a pro-apoptotic/necrotic effect on EPCs (Fig. 1b).

In the following descriptive and functional investigations, we focused on the comparison of 1 and $5 \mu \mathrm{g} / \mathrm{ml}$ $\mathrm{mCRP}$ and pCRP, respectively, to adjust for molarity of the pentameric structure of $\mathrm{pCRP}$.

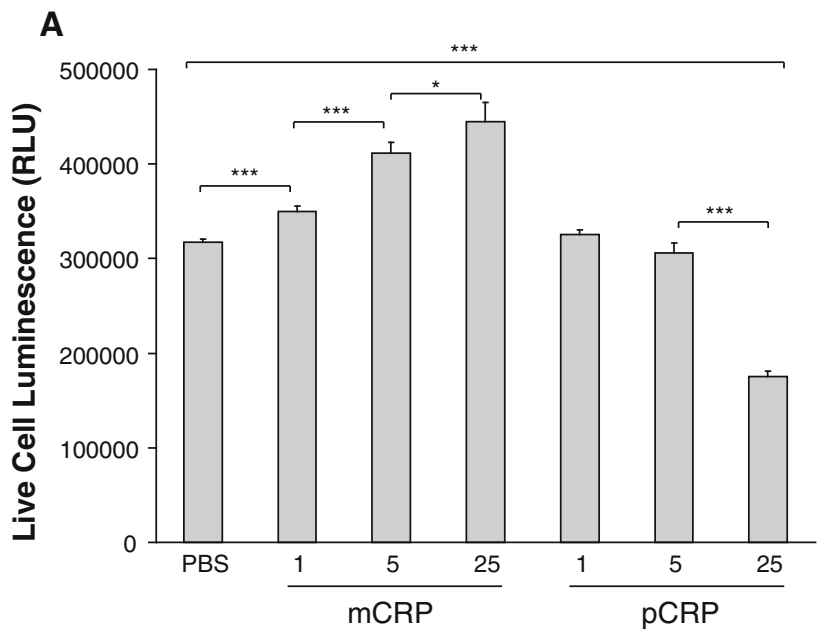

B

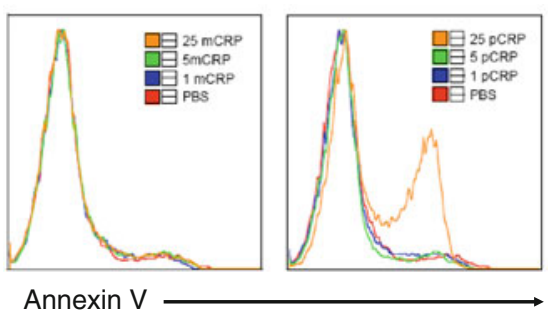

Fig. 1 Cytotoxicity assay after $72 \mathrm{~h}$ of EPC treatment with mCRP and pCRP. a Viable cells were measured by the CytoTox-Glo ${ }^{\mathrm{TM}}$ cytotoxicity assay. The bars represent the relative luminesce unit (RLU) calculated for the viable cells, i.e. dead cells deducted from total cells, mean and SD of $n=3$. b. Histograms of one representative experiment showing the binding of the apoptosis marker Annexin V to EPCs using a FITC-labelled Annexin V antibody detected by flow cytometry 
pCRP but not mCRP treatment decreased the number of AcLDL and ulex lectin double-positive cells

One phenotypic characteristic for EPCs is their ability to take up AcLDL and to bind ulex lectin. The uptake of AcLDL and the binding of ulex lectin were investigated by immunofluorescence staining using Dil-labelled AcLDL and FITC-labelled ulex lectin. The percentage of cells double positive for uptake of Dil-labelled AcLDL and binding of FITC-labelled ulex lectin after treatment with $1 \mu \mathrm{g} / \mathrm{ml} \mathrm{mCRP}, 5 \mu \mathrm{g} / \mathrm{ml} \mathrm{pCRP}$ and PBS was $36 \pm 7$, $42 \pm 11$ and $12 \pm 3 \%$, respectively (Fig. 2a). The percentage of double-positive cells indicating EPC phenotype was significantly decreased after pCRP treatment $(12 \pm 3 \%, p<0.05$, Fig. 2a). In contrast, EPCs treated with mCRP $(1 \mu \mathrm{g} / \mathrm{ml})$ were not affected and showed a similar percentage of double-positive cells compared to the PBS control.

Functional characteristics of EPCs are differentially affected by mCRP and pCRP

EPCs were treated with mCRP $(1 \mu \mathrm{g} / \mathrm{ml})$, pCRP $(5 \mu \mathrm{g} / \mathrm{ml})$ or PBS and then assessed for their ability to form colony forming units (CFU-Hill) and to support endothelial tube formation. Treatment of EPCs with pCRP significantly increased the number of CFUs $(40 \pm 5, p<0.001)$, whereas mCRP $(19 \pm 2)$ did not affect the number of CFUs compared to PBS (25 \pm 3 ) treated cells (Fig. 2b). The effect of mCRP $(1 \mu \mathrm{g} / \mathrm{ml})$ and pCRP $(5 \mu \mathrm{g} / \mathrm{ml})$ treatment on the ability of EPCs to support formation of endothelial tubuli in a co-culture with human umbilical
A
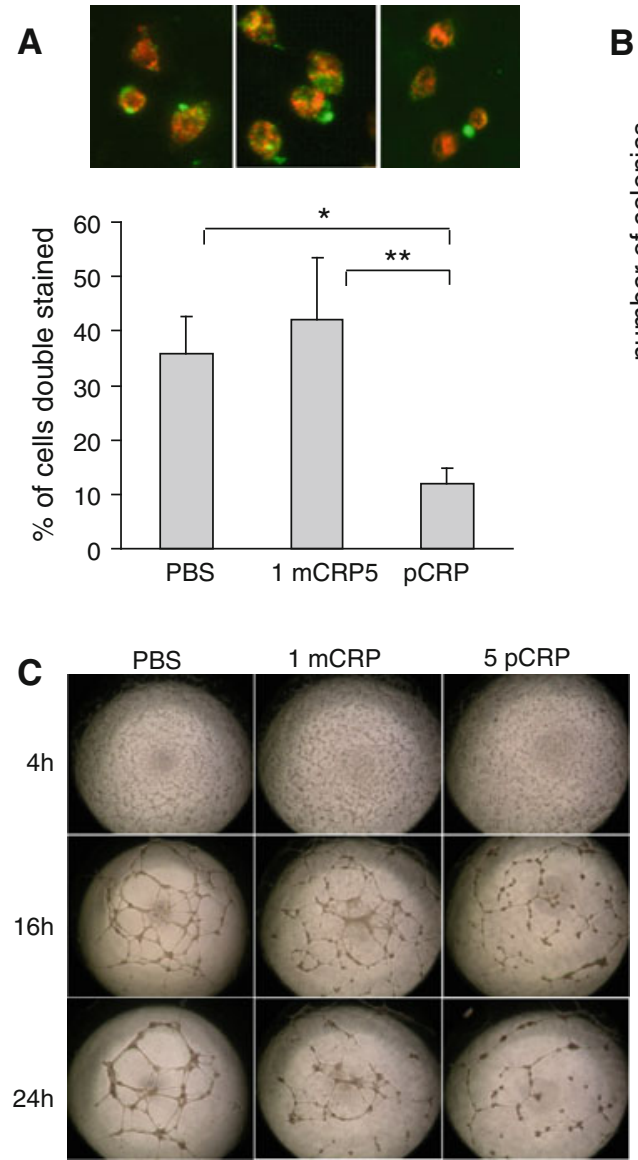

Fig. 2 The effect of $\mathrm{mCRP}(1 \mu \mathrm{g} / \mathrm{ml})$ or pCRP $(5 \mu \mathrm{g} / \mathrm{ml})$ on phenotype and function of EPCs. a Binding of ulex lectin and uptake of AcLDL after $72 \mathrm{~h}$ of culture of EPCs in the presence or absence of mCRP or pCRP visualised with FITC-labelled ulex lectin and Dillabelled AcLDL, respectively. The photomicrographs show a typical optical field from one representative experiment. The bar graph shows the percentage of double-positive cells, mean and SD of $n=3$. b The number of colony forming units (CFU-Hill) visualised by Giemsa staining. The bars represent the total number of colonies per
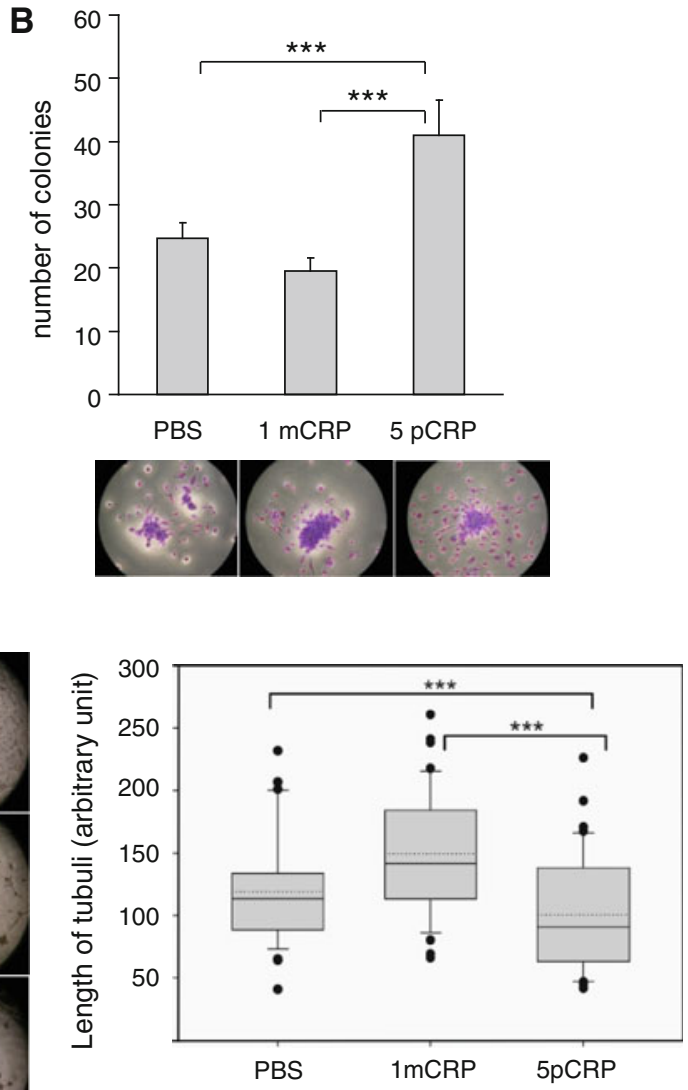

well in a 24-well plate, mean and SD of $n=3$. c Endothelial tube formation assay after $72 \mathrm{~h}$ of culture of EPCs in the presence or absence of mCRP or pCRP. The treated EPCs were co-cultured with HUVECs for additional 4, 16 and $24 \mathrm{~h}$, respectively. The photomicrographs show the results of a representative experiment. The length of the tubuli was assessed after $16 \mathrm{~h}$. The box plot represents the mean (dotted line), median (solid line) and SD of three independent experiments 

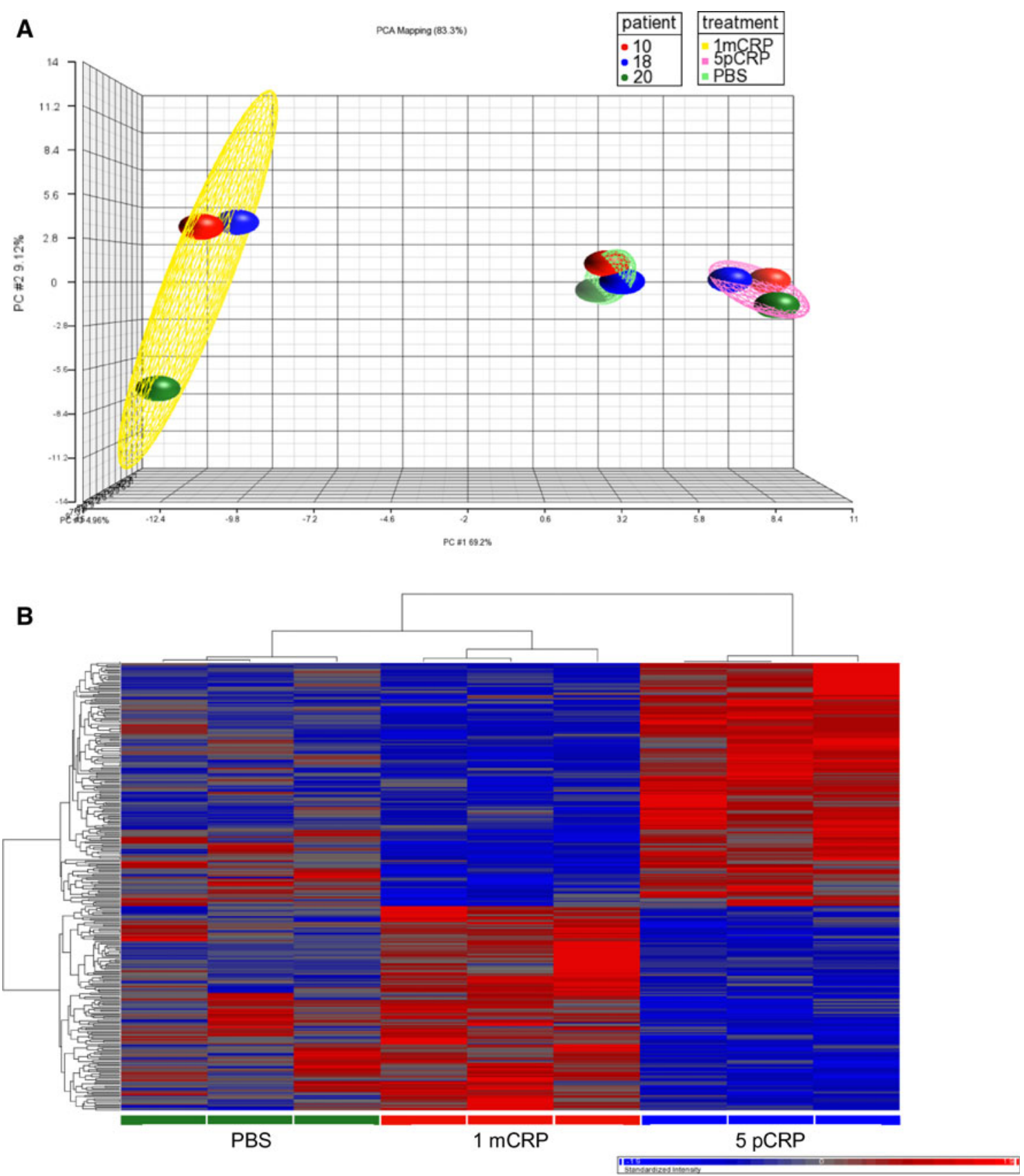

Fig. 3 a Principal component analysis (PCA) of the source of variation in the sample gene expression. This was an exploratory multivariate statistical technique that was used to simplify the complex microarray changes that occur in three individuals (patient 10, 18 and 20) and in response to different valency CRP. This is done by reducing the dimensionality of the data matrix by finding $r$ new variables (that sum the expression of multiple genes into single axes); shown here are the average signal of each sample along the threedimensional virtual space of the first three principal components. The

vein endothelial cells was determined using a Matrigel $^{\mathrm{TM}}$ assay. Tube formation occurred at $4 \mathrm{~h}$ of incubation on Matrigel $^{\mathrm{TM}}$ and was maximal at $16 \mathrm{~h}$ of incubation (PBSpanel, Fig. 2c). After $24 \mathrm{~h}$, the tube network started to plot clearly shows that the variation in gene expression is dominated by the CRP treatment and not the patient source. b Hierarchical clustering of the gene expression response to CRP valency; 320 differentially expressed genes are plotted according to their degree of respective co-expression. Columns represent samples, while rows represent genes. The treatment of each sample is listed at the bottom. The degree of correlation between genes (left) or samples (top) is plotted in a tree view fashion

break up, and this was facilitated when pCRP-treated EPCs were used (Fig. 2c). Neither mCRP nor pCRP affected the number of tubuli or branching points. However, the length of the tubuli was slightly increased by EPCs treated with 
Table 1 Genes up- and down-regulated in EPCs treated with mCRP $(1 \mu \mathrm{g} / \mathrm{ml})$

\begin{tabular}{|c|c|c|c|c|c|}
\hline \multirow[t]{2}{*}{ Gene symbol } & \multirow[t]{2}{*}{ Gene name } & \multicolumn{2}{|c|}{ mCRP treatment } & \multicolumn{2}{|c|}{ pCRP treatment } \\
\hline & & Fold change & $p$ Value & Fold change & $p$ Value \\
\hline \multicolumn{6}{|c|}{ Up-regulated genes } \\
\hline IFI44L & Interferon-induced protein 44 -like & 10.04 & 0.001 & -2.36 & 0.61 \\
\hline$M X 1$ & Myxovirus (influenza virus) resistance 1 & 7.58 & 0.008 & -2.68 & 0.46 \\
\hline$O A S 2$ & $2^{\prime}-5^{\prime}$-Oligoadenylate synthetase $2,69 / 71 \mathrm{kDA}$ & 6.84 & 0.001 & -2.56 & 0.31 \\
\hline$L Y 6 E$ & Lymphocyte antigen 6 complex, locus E & 6.18 & 0.003 & -2.64 & 0.33 \\
\hline$I F I 27$ & Interferon, alpha-inducible protein 27 & 6.11 & 0.040 & -2.52 & 0.63 \\
\hline IFI44 & Interferon-induced protein 44 & 6.05 & 0.0005 & -2.43 & 0.35 \\
\hline IFI6 & Interferon, alpha-inducible protein 6 & 5.09 & 0.0004 & -2.51 & 0.20 \\
\hline EPSTI1 & Epithelial stromal interaction 1 (breast) & 4.94 & 0.026 & -2.06 & 0.94 \\
\hline$O A S 3$ & $2^{\prime}-5^{\prime}$-Oligoadenylate synthetase $3,100 \mathrm{kDa}$ & 4.28 & 0.005 & -2.90 & 0.10 \\
\hline IFIT3 & Interferon-induced protein with tetratricopeptide repeats 3 & 3.87 & 0.048 & -2.92 & 0.22 \\
\hline SAMD9L & Sterile alpha motif domain containing 9-like & 3.73 & 0.002 & -3.04 & 0.02 \\
\hline GLTPD2 & Glycolipid transfer protein domain containing 2 & 3.65 & 0.009 & -2.02 & 0.96 \\
\hline$E I F 2 A K 2$ & Eukaryotic translation initiation factor 2-alpha kinase 2 & 3.42 & 0.007 & -2.14 & 0.65 \\
\hline DDX60 & DEAD (Asp-Glu-Ala-Asp) box polypeptide 60 & 3.28 & 0.031 & -2.24 & 0.57 \\
\hline SPINT4 & Serine peptidase inhibitor, Kunitz type 4 & 3.23 & 0.026 & -2.18 & 0.64 \\
\hline IRF7 & Interferon-regulatory factor 7 & 3.14 & 0.032 & -2.22 & 0.57 \\
\hline PARP9 & Poly (ADP-ribose) polymerase family, member 9 & 3.10 & 0.031 & -2.69 & 0.12 \\
\hline GPR87 & G protein-coupled receptor 87 & 3.08 & 0.017 & -2.09 & 0.77 \\
\hline RETSAT & Retinol saturase (all-trans-retinol 13, 14-reductase) & 3.08 & 0.022 & -2.30 & 0.38 \\
\hline CLDN4 & Claudin 4 & 3.04 & 0.032 & -2.27 & 0.46 \\
\hline IRF9 & Interferon-regulatory factor 9 & 3.01 & 0.032 & -2.53 & 0.18 \\
\hline$O A S L$ & $2^{\prime}-5^{\prime}$-Oligoadenylate synthetase-like & 2.97 & 0.038 & -2.46 & 0.23 \\
\hline PARP12 & Poly (ADP-ribose) polymerase family, member 12 & 2.88 & 0.037 & -2.50 & 0.17 \\
\hline STAT1 & Signal transducer and activator of transcription 1 & 2.87 & 0.009 & -2.29 & 0.24 \\
\hline$H I S T 1 H 2 A K$ & Histone cluster $1, \mathrm{H} 2 \mathrm{ak}$ & 2.85 & 0.039 & -2.25 & 0.43 \\
\hline PEX11A & Peroxisomal biogenesis factor 11 alpha & 2.75 & 0.014 & -2.50 & 0.06 \\
\hline POMT2 & Protein-O-mannosyltransferase 2 & 2.61 & 0.003 & -2.43 & 0.09 \\
\hline EPB41 & Erythrocyte membrane protein band 4.1 & 2.56 & 0.014 & -2.37 & 0.07 \\
\hline \multicolumn{6}{|c|}{ Down-regulated genes } \\
\hline$M L L T 3$ & Myeloid/lymphoid or mixed-lineage leukaemia; translocated to, 3 & -3.48 & 0.007 & 2.08 & 0.80 \\
\hline SOX1 & SRY (sex determining region Y)-box 1 & -3.25 & 0.002 & 2.04 & 0.86 \\
\hline SRD5A2 & Steroid-5-alpha-reductase, alpha polypeptide 2 & -3.16 & 0.008 & 2.55 & 0.10 \\
\hline ACSM1 & Acyl-CoA synthetase medium-chain family member 1 & -3.16 & 0.003 & 2.28 & 0.27 \\
\hline RNF133 & Ring finger protein 133 & -3.02 & 0.035 & 2.16 & 0.64 \\
\hline ROR1 & Receptor tyrosine kinase-like orphan receptor 1 & -2.99 & 0.032 & 2.03 & 0.92 \\
\hline ZEB1 & Zinc finger E-box-binding homoeobox 1 & -2.99 & 0.001 & 2.02 & 0.91 \\
\hline ZNF300 & Zinc finger protein 300 & -2.96 & 0.011 & 2.12 & 0.64 \\
\hline PRAMEF 21 & PRAME family member 21 & -2.93 & 0.038 & 2.37 & 0.30 \\
\hline$S R D 5 A 3$ & Steroid 5 alpha-reductase-3 & -2.87 & 0.024 & 2.26 & 0.37 \\
\hline RPL21 & Ribosomal protein L21 & -2.64 & 0.008 & 2.41 & 0.05 \\
\hline CARD18 & Caspase recruitment domain family, member 18 & -2.60 & 0.025 & 2.33 & 0.15 \\
\hline PCDHGB6 & Protocadherin gamma subfamily B, 6 & -2.50 & 0.021 & 2.57 & 0.01 \\
\hline GRIN1 & Glutamate receptor, ionotropic & -2.42 & 0.008 & 2.49 & 0.004 \\
\hline
\end{tabular}

Up- and down-regulated genes by mCRP $(n=3)$ compared to PBS-treated control EPCs were selected based on a Bayesian "volcano plot" of expression with a fold change in expression level greater than twofold, and a $p$ value $<0.05$ as determined by student's $t$ test

The fold change effect of pCRP treatment, as compared to PBS-treated control EPCs, for the differentially expressed genes was also determined 
Table 2 Genes up- and down-regulated in EPCs treated with pCRP $(5 \mu \mathrm{g} / \mathrm{ml})$

\begin{tabular}{|c|c|c|c|c|c|}
\hline \multirow[t]{2}{*}{ Gene symbol } & \multirow[t]{2}{*}{ Gene name } & \multicolumn{2}{|c|}{ mCRP treatment } & \multicolumn{2}{|c|}{ pCRP treatment } \\
\hline & & Fold change & $p$ Value & Fold change & $p$ Value \\
\hline \multicolumn{6}{|c|}{ Up-regulated genes } \\
\hline MFAP4 & Microfibrillar-associated protein 4 & 3.60 & 0.0010 & -2.03 & 0.855 \\
\hline$R A B G G T B$ & Rab geranylgeranyltransferase, beta subunit & 3.51 & 0.0013 & -2.05 & 0.793 \\
\hline FAM116B & Family with sequence similarity 116 , member B & 3.16 & 0.0040 & -2.00 & 0.994 \\
\hline DDIT3 & DNA damage-inducible transcript 3 & 3.08 & 0.0004 & -2.07 & 0.578 \\
\hline PROK2 & Prokinectin 2 & 3.08 & 0.0486 & -2.13 & 0.690 \\
\hline$R P L 7 A$ & Ribosomal protein $\mathrm{L} 7 \mathrm{a}$ & 3.05 & 0.0311 & -2.43 & 0.215 \\
\hline$P A B P C 4$ & Poly(A)-binding protein, cytoplasmic 4 (inducible form) & 3.04 & 0.0042 & -2.07 & 0.704 \\
\hline CELSR1 & Cadherin, EGF LAG seven-pass G-type receptor 1 & 3.01 & 0.0104 & -2.12 & 0.570 \\
\hline FRMD7 & FERM domain containing 7 & 3.01 & 0.0499 & -2.10 & 0.739 \\
\hline ZNF695 & Zinc finger protein 695 & 3.00 & 0.0199 & -2.04 & 0.859 \\
\hline$H E R C 2$ & Hect domain and RLD2 & 2.99 & 0.0286 & -2.00 & 0.998 \\
\hline$R P L 13 L$ & Ribosomal protein L13 pseudogene 5 & 2.98 & 0.0094 & -2.12 & 0.566 \\
\hline ZNF277 & Zinc finger protein 277 & 2.96 & 0.0002 & -2.11 & 0.325 \\
\hline$L R A T$ & Lectin retinol acyltransferase & 2.90 & 0.0157 & -2.12 & 0.572 \\
\hline STAG3L4 & Stromal antigen 3 -like 4 & 2.87 & 0.0329 & -2.25 & 0.368 \\
\hline$A B H D 14 B$ & Abhydrolase domain containing 14B & 2.86 & 0.0488 & -2.17 & 0.554 \\
\hline$A V P I 1$ & Arginine vasopressin-induced 1 & 2.85 & 0.0062 & -2.21 & 0.258 \\
\hline$D Y M$ & Dymeclin & 2.82 & 0.0005 & -2.05 & 0.652 \\
\hline ROM1 & Retinal outer segment membrane protein 1 & 2.81 & 0.0099 & -2.30 & 0.163 \\
\hline$R A C 3$ & ras-related $\mathrm{C} 3$ botulinum toxin substrate 3 & 2.81 & 0.0076 & -2.10 & 0.558 \\
\hline CCDC104 & Coiled-coil domain containing 104 & 2.81 & 0.0002 & -2.15 & 0.164 \\
\hline SLC16A10 & Solute carrier family 16, member 10 & 2.80 & 0.0082 & -2.15 & 0.398 \\
\hline PHACTR1 & Phosphatase and actin regulator 1 & 2.80 & 0.0079 & -2.04 & 0.813 \\
\hline PCOLCE2 & Procollagen C-endopeptidase enhancer 2 & 2.76 & 0.0379 & -2.10 & 0.657 \\
\hline ZNF581 & Zinc finger protein 581 & 2.75 & 0.0207 & -2.11 & 0.602 \\
\hline$C R P$ & C-reactive protein, pentraxin related & 2.72 & 0.0400 & -2.15 & 0.528 \\
\hline$S I R P G$ & Signal-regulatory protein gamma & 2.70 & 0.0129 & -2.24 & 0.210 \\
\hline$N N M T$ & Nicotinamide N-methyltransferase & 2.70 & 0.0115 & -2.07 & 0.685 \\
\hline$E I F 2 A$ & Eukaryotic translation initiation factor $2 \mathrm{~A}$ & 2.69 & 0.0134 & -2.22 & 0.249 \\
\hline$F A B P 2$ & Fatty acid-binding protein 2 , intestinal & 2.69 & 0.0067 & -2.13 & 0.411 \\
\hline$R G M A$ & RGM domain family, member A & 2.69 & 0.0146 & -2.08 & 0.636 \\
\hline POLRIE & Polymerase (RNA) polypeptide E, $53 \mathrm{kDa}$ & 2.61 & 0.0358 & -2.18 & 0.385 \\
\hline LETMD1 & LETM1 domain containing 1 & 2.60 & 0.0168 & -2.20 & 0.258 \\
\hline FTHL11 & Ferritin, heavy polypeptide-like 11 & 2.59 & 0.0422 & -2.25 & 0.261 \\
\hline CSNK2A2 & Casein kinase 2, alpha prime polypeptide & 2.57 & 0.0036 & -2.27 & 0.061 \\
\hline$C C D C 140$ & Coiled-coil domain containing 140 & 2.53 & 0.0332 & -2.17 & 0.346 \\
\hline$P A X 7$ & Paired box 7 & 2.49 & 0.0343 & -2.25 & 0.190 \\
\hline ZFAND1 & Zinc finger, AN 1-type domain 1 & 2.49 & 0.0175 & -2.21 & 0.175 \\
\hline RAB39 & RAB39, member RAS oncogene family & 2.44 & 0.0350 & -2.25 & 0.156 \\
\hline PCDHGB6 & Protocadherin gamma subfamily B, 6 & 2.44 & 0.0115 & -2.38 & 0.021 \\
\hline GRIN1 & Glutamate receptor, inotropic, $N$-methyl D-aspartate 1 & 2.37 & 0.0041 & -2.31 & 0.008 \\
\hline RPL21 & Ribosomal protein L21 & 2.30 & 0.0474 & -2.49 & 0.008 \\
\hline \multicolumn{6}{|c|}{ Down-regulated genes } \\
\hline$A B C A 13$ & ATP-binding cassette, sub-family A (ABC1), member 13 & -5.39 & 0.0009 & 2.02 & 0.931 \\
\hline$L T F$ & Lactotransferrin & -5.11 & 0.0427 & 2.27 & 0.652 \\
\hline$P D A P 1$ & PDGFA associated protein 1 & -5.04 & 0.0005 & 2.23 & 0.353 \\
\hline
\end{tabular}


Table 2 continued

\begin{tabular}{|c|c|c|c|c|c|}
\hline \multirow[t]{2}{*}{ Gene symbol } & \multirow[t]{2}{*}{ Gene name } & \multicolumn{2}{|c|}{ mCRP treatment } & \multicolumn{2}{|c|}{ pCRP treatment } \\
\hline & & Fold change & $p$ Value & Fold change & $p$ Value \\
\hline IFIT1 & Interferon-induced protein with tetratricopeptide repeats 1 & -4.39 & 0.0264 & 2.86 & 0.175 \\
\hline TXNIP & Thioredoxin-interacting protein & -3.75 & 0.0207 & 2.03 & 0.917 \\
\hline UGT1A3 & UDP glucoronsyltransferase 1 family, polypeptide A3 & -3.60 & 0.0453 & 2.05 & 0.891 \\
\hline RIMS3 & Regulating synaptic membrane exocytosis 3 & -3.47 & 0.0004 & 2.04 & 0.906 \\
\hline$P K D 2 L 1$ & Polycystic kidney disease 2 -like 1 & -3.47 & 0.0191 & 2.34 & 0.336 \\
\hline$M T 1 L$ & Metallothionein 1L (gene/pseudogene) & -3.37 & 0.0006 & 2.07 & 0.666 \\
\hline OXTR & Oxytocin receptor & -3.30 & 0.0464 & 2.04 & 0.906 \\
\hline SIGLEC5 & Sialic acid-binding Ig-like lectin 5 & -3.29 & 0.0350 & 2.03 & 0.912 \\
\hline$N C F 1$ & Neutrophil cytosolic factor 1 & -3.25 & 0.0308 & 2.00 & 0.987 \\
\hline LRRC39 & Leucin rich repeat containing 39 & -3.20 & 0.0082 & 2.14 & 0.549 \\
\hline
\end{tabular}

Up- and down-regulated genes by pCRP $(n=3)$ compared to PBS-treated control EPCs were selected based on a Bayesian "volcano plot" of expression with a fold change in expression level greater than twofold, and a $p$ value $<0.05$ as determined by student's $t$ test

The fold change effect of mCRP treatment, as compared to PBS-treated control EPCs, for the differentially expressed genes was also determined

mCRP, whereas the ability of these cells to support tube formation was significantly reduced after treatment with pCRP, respectively ( $p<0.001$, Fig. 2c).

Differential effect of mCRP and pCRP on the gene expression profile of EPCs

RNA for whole-genome gene expression analysis was extracted after a 72-h culture period of in vitro expanded cord blood-derived $\mathrm{CD}_{3} 4^{+}$cells on fibronectin-coated dishes. Cells were treated with mCRP $(1 \mu \mathrm{g} / \mathrm{ml}), \mathrm{pCRP}$ $(5 \mu \mathrm{g} / \mathrm{ml})$ or PBS in EGM-2. In addition, RNA was extracted before the 72-h culture period to determine the background of differentially expressed genes induced by the EPC differentiation process during the 72-h culture period on fibronectin-coated dishes. The microarray analysis was undertaken in three biological repeats (three different cord blood donors) on beadchips containing $>48,000$ different probes. Box and whisker plots confirmed that the normalisation of the arrays achieved comparable dynamic range of the different samples (supplementary Fig. 1). In contrast, principal component analysis (PCA) demonstrated that the gene expression, induced by either mCRP or pCRP, was systematically distinct across the three donors (Fig. 3a). Hierarchical clustering of 320 differentially expressed genes further demonstrated that mCRP and pCRP treatment differentially induced coordinate programmatic gene expression and differentiation (Fig. 3b).

The gene expression analysis comparing EPCs treated with mCRP to EPCs treated with PBS detected 42 differentially expressed genes, of which 28 were significantly up-regulated and 14 were down-regulated (at least twofold change, $p<0.05$ ) (Table 1). Comparing expression patterns of EPCs treated with pCRP to PBStreated EPCs detected 86 differentially expressed genes, of which 42 were up-regulated and 44 were down-regulated (at least twofold change, $p<0.05$ ) (Table 2). As demonstrated in Table 1, analysis of the differentially expressed genes revealed that $\mathrm{mCRP}$ and pCRP showed opposing effects, meaning that the genes up-regulated by mCRP were down-regulated by $\mathrm{pCRP}$, and vice versa.

mCRP, but not pCRP, stimulates the expression of interferon- $\alpha$ responsive genes

To benchmark differential gene expression in EPCs in response to either $\mathrm{mCRP}$ or $\mathrm{pCRP}$ treatment to existing microarray literature and to gain more biological insight from the gene expression pattern specific for mCRP and pCRP treatment, we have employed Ingenuity Pathway Analysis $^{\circledR}$ (IPA) and Gene Set Enrichment Analysis [41]. Those genes that were up-regulated in response to mCRP exhibited extensive cross interactions, centred around interferon- $\alpha$ (Table 1; Fig. 4). Treatment with pCRP led to a highly different response in the gene expression profile centred around the MAPK pathway, DDIT3/ GADD153 and consequent cell growth (ribosomal subunits), and cell cycle regulators such as p21/CDKN1A (Table 2, Fig. 5). Genes with significant down-regulation in response to $\mathrm{mCRP}$ and pCRP treatments are described in Tables 1 and 2. An IPA network analysis of selected down-regulated genes in response to mCRP and pCRP, respectively, is depicted in Supplementary Figures 2 and 3.

The gene expression was verified by quantitative realtime PCR with RNA isolated from mCRP $(1 \mu \mathrm{g} / \mathrm{ml})$, 
Fig. 4 Ingenuity pathways analysis. Network of upregulated genes in response to $1 \mu \mathrm{g} / \mathrm{ml} \mathrm{mCRP}$. Networks of gene/gene product interaction were generated using IPA (Ingenuity ${ }^{\circledR}$ Systems, http://www.ingenuity.com). Genes or gene products are represented as nodes, and the biological relationship between two nodes is represented as an edge (line). All edges are supported by at least one published reference. Solid edges represent a direct relationship and dashed edges represent an indirect relationship. The red node colour represents up-regulation in response to mCRP and the colour intensity indicates the degree of up-regulation. The shape of each node represents the functional class of the gene product, as shown in the legend

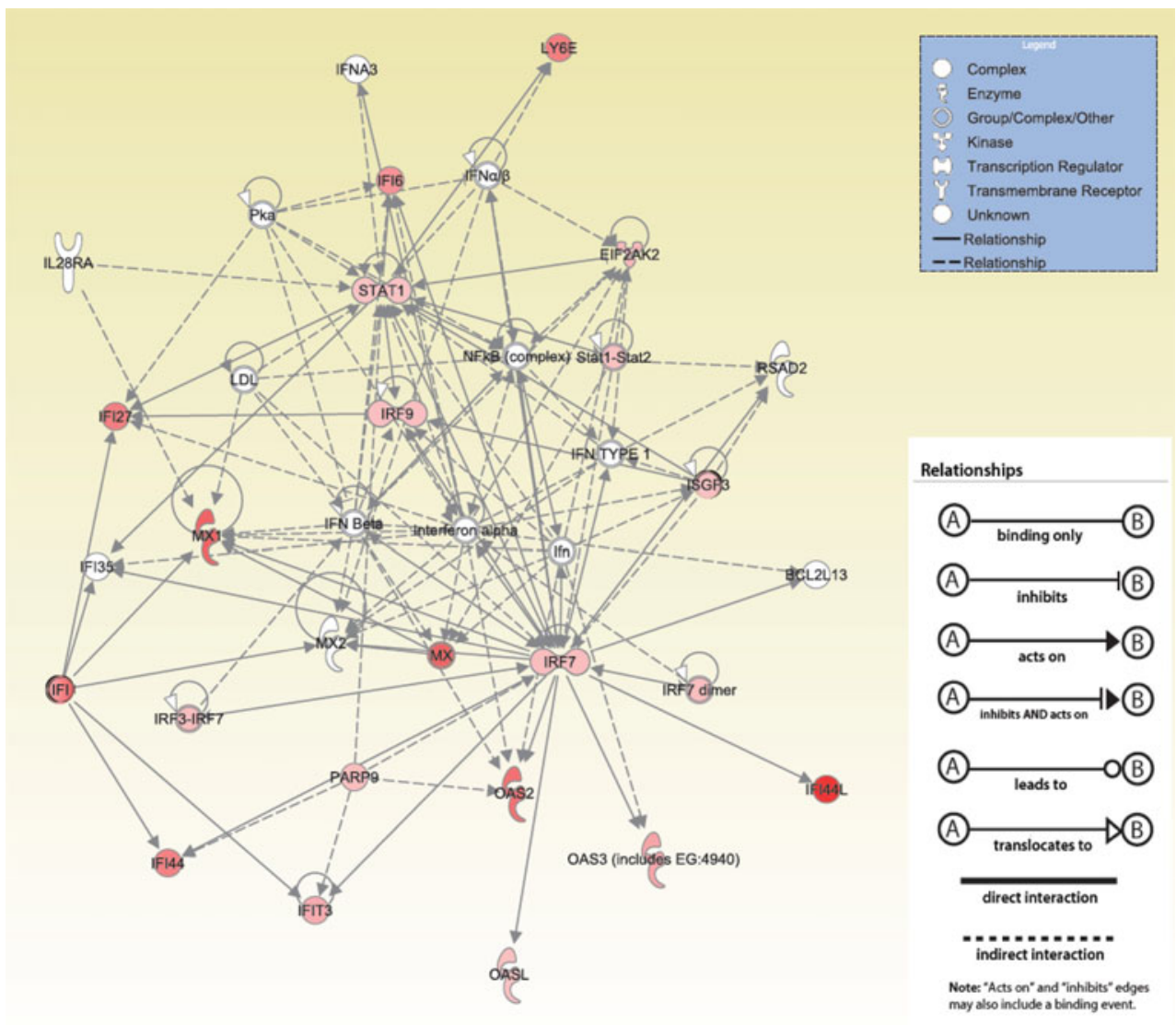

pCRP $(5 \mu \mathrm{g} / \mathrm{ml})$ or PBS-treated EPCs and expressed as fold change in gene expression compared to the PBS-treated control (Fig. 6). Confirming the results of the gene array, IFI44L was the most up-regulated gene in response to mCRP treatment (29.3-fold \pm 17$)$ followed by MX1 (8.3-fold \pm 2.2 ) and OAS2 (8.6 \pm 2.4$)$ (Fig. 6). Treatment with pCRP but not mCRP led to increased expression of DDIT3 $(4.4 \pm 0.97)$ and PROK2 $(2.2 \pm 0.86)$ (Fig. 6).

The effects of IFN $\alpha 2 \mathrm{~A}$ on phenotypic and functional characteristics of EPCs

The percentage of EPCs double positive for the uptake of AcLDL and binding of ulex lectin was significantly higher $(p<0.001)$ in the presence of IFN $\alpha 2 \mathrm{~A}$ or mCRP compared to pCRP (Fig. 7a). Also, compared to pCRP-treated EPCs, IFN $\alpha 2 \mathrm{~A}$ or mCRP-treated EPCs gave rise to significantly fewer colonies $(p<0.01)$ (Fig. 7b). Compared to PBS, mCRP or IFN $\alpha 2 \mathrm{~A}$-treated EPCs, pCRP-treated EPCs showed a reduced ability to stimulate endothelial tube formation assessed by the length of endothelial tubes in a Matrigel $^{\mathrm{TM}}$ assay with HUVECs (Fig. 7c).

\section{Discussion}

This study aimed to assess the effects of pentameric (p)CRP and monomeric (m)CRP on function and differentiation of EPCs. The generation of mCRP by dissociation of pCRP on the cell membrane of activated platelets has been recently described as a pathophysiological mechanism to localise inflammatory reactions, e.g. at developing atherosclerotic plaques [15]. The regenerative capability and the numbers of circulating EPCs have been associated with atherosclerotic plaque development and thus we hypothesised that CRP, particularly mCRP, is a potential regulator of EPC function.

The two major findings of this study are: (1) mCRP and pCRP at concentrations similar to the reported serum levels of CRP in patients with atherosclerotic disease [2] induce an opposing gene expression profile in cord blood-derived EPCs as well as differential effects on the functional capacity of EPCs. (2) The highly up-regulated genes in response to mCRP but not to pCRP treatment are centred around the proinflammatory actions of interferon- $\alpha$ and are highly related to up-regulated genes in patients with systemic lupus erythematodes (SLE). Interferon- $\alpha 2 \mathrm{~A}$ treatment induced a functional response in EPCs similar to mCRP treatment. 
Fig. 5 Ingenuity pathways analysis. Network of up-regulated genes in response to $5 \mu \mathrm{g} / \mathrm{ml} \mathrm{pCR} P$. Networks of gene/gene product interaction were generated using IPA (Ingenuity ${ }^{\circledR}$ Systems, http://www.ingenuity.com). Genes or gene products are represented as nodes, and the biological relationship between two nodes is represented as an edge (line). All edges are supported by at least one published reference. Solid edges represent a direct relationship and dashed edges represent an indirect relationship. The red node colour represents up-regulation in response to $\mathrm{pCRP}$. The shape of each node represents the functional class of the gene product, as shown in the legend of Fig. 4

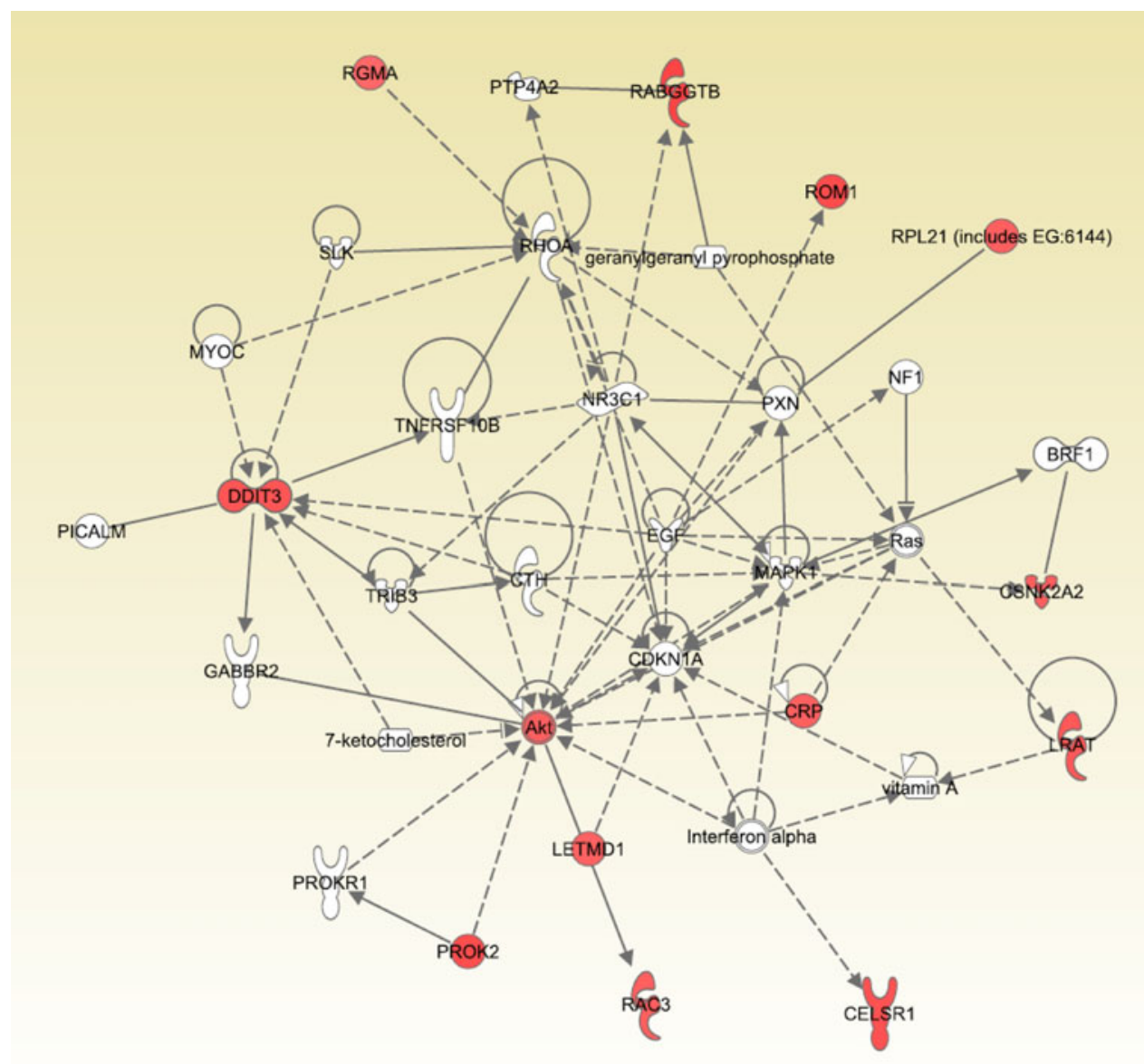

2000-2010 Ingenuity Systems, Inc. All rights reserved.
Differential effects of mCRP and pCRP on monocyte and platelet function have been observed in previous studies of our group and others [15, 16, 40]. EPC function following pCRP treatment has been extensively examined in previous studies [7, 19, 38, 64], but the differential effects of CRP isoforms on EPCs have not been investigated yet. EPCs are thought to play a key role in the regeneration of injured/inflamed endothelium, and reduced functional capacity of EPCs has been correlated to serum levels of CRP [9]. Therefore, CRP (either monomeric or pentameric) may directly account for the impaired EPC function in patients with chronically elevated serum CRP levels in atherosclerotic disease. Our in vitro study confirms the results of previous studies showing decreased viability and induction of apoptosis with pCRP concentrations $>10 \mu \mathrm{g} / \mathrm{ml}[5,19,52,64]$. Furthermore, we are able to confirm that pCRP, but not mCRP, decreases the number of cells double positive for the uptake of AcLDL and the binding of ulex lectin, which has been described as a common EPC phenotype $[24,29,48,69]$. The ability of EPCs to stimulate endothelial tube formation in co-cultures with HUVECs has been used to describe the pro-angiogenic functions of
EPCs [8, 24, 64]. In line with other reports [64], our results indicate that pCRP directly impairs endothelial tube formation and this occurred at the concentration of $5 \mu \mathrm{g} / \mathrm{ml}$, which was not cytotoxic to the EPCs, thereby indicating that EPC differentiation rather than viability in response to pCRP treatment impaired the ability of EPCs to support endothelial tube formation. This interpretation is supported by the decreased number of AcLDL and ulex lectin double-positive cells after pCRP treatment and the significant increase in the number of $\mathrm{CFU}$ in response to pCRP treatment.

The increase in CFUs may be explained by the up-regulation of two genes (DDIT3 and PROK2) in response to pCRP treatment. PROK2 has been shown to increase the number of CFUs and to enhance progenitor cell mobilisation [36] and DDIT3 (also known as GADD153 or CHOP), although also associated with the response to oxidative stress [12, 42], increased the number of CFUs in erythroid cells [10]. Interestingly, pCRP treatment of human coronary vascular smooth muscle cells with $5 \mu \mathrm{g} / \mathrm{ml}$ of pCRP also led to a $>2$-fold increase in expression of DDIT3 (GADD153) [5], which has been reproduced by others with higher concentrations of pCRP $(25 \mu \mathrm{g} / \mathrm{ml})$ [52]. 


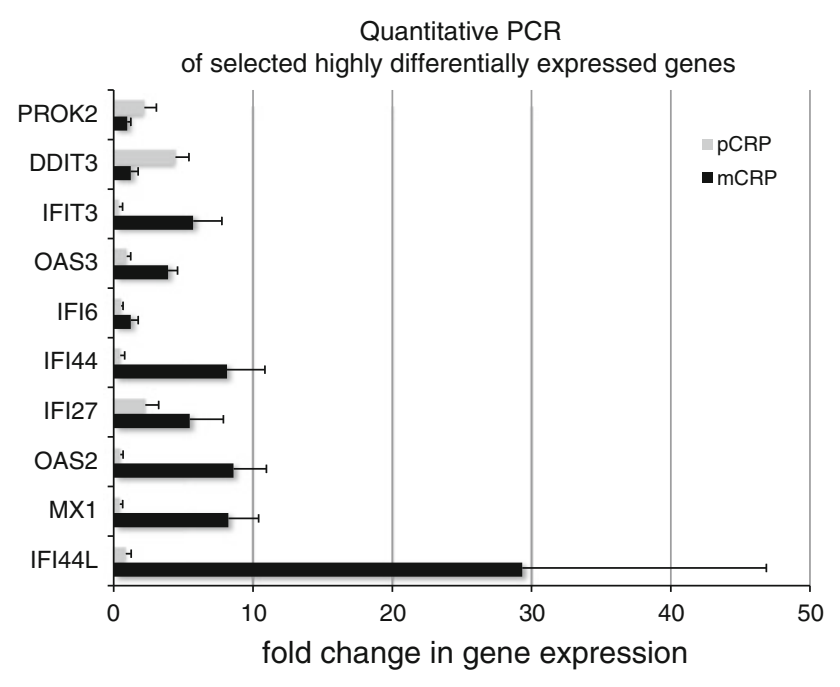

Fig. 6 Validation of the expression of selected highly upregulated genes in mCRP $(1 \mu \mathrm{g} / \mathrm{ml})$ and pCRP $(5 \mu \mathrm{g} / \mathrm{ml})$-treated EPCs by quantitative real-time PCR. Validation of gene expression by quantitative real-time PCR. The mean in gene expression from EPCs derived from three individual cord blood donors was obtained using differences in cycle threshold between the gene and $18 \mathrm{~s}(\Delta \mathrm{Ct})$. The fold change in difference $(\Delta \Delta \mathrm{Ct})$ in gene expression in the treated samples compared to the PBS control samples was determined $(2 \Delta \Delta \mathrm{Ct})$ and expressed in the diagram as mean and SEM of $n=3$. Grey bars represent pCRP and black bars represent mCRP-treated EPCs

In view of our observations showing increased CFUs with low concentrations of pCRP and decreased viability and increased apoptosis with higher concentrations, we hypothesise that moderately elevated levels of pCRP under non-inflammatory conditions may have a different impact on EPC differentiation and function as compared to inflammatory conditions. This is supported by the observation that the endothelial colony forming capacity of EPCs is positively correlated to pCRP levels in healthy volunteers [9]. Whereas under inflammatory conditions, such as those present in atherosclerotic disease, localised dissociation of pCRP to mCRP may occur [15]. This in turn could then have a negative biological effect on EPC numbers and function as observed in patients with atherosclerosis [55, 67, 68].

In our in vitro study, mCRP treatment of EPCs did not decrease the numbers of AcLDL and ulex lectin positive cells and there was also no decrease in their capacity to support endothelial tube formation with mCRP treatment, which furher highlights the differential effects of the two CRP isoforms that has been shown in vitro in various cell types [28, 32-35, 56, 72]. We compared the concentrations of $1 \mu \mathrm{M}$ mCRP with $5 \mu \mathrm{M}$ pCRP to account for the differences in molarity between pCRP (115 kDa) and mCRP (23 kDa).

The substantial differences in the effects of mCRP and pCRP were confirmed in whole-genome gene expression analysis. The genes up-regulated by mCRP are known to be responsive to the pro-inflammatory interferon- $\alpha$. Among the 28 highly up-regulated genes in response to mCRP treatment were nine interferon-inducible genes (IFI44L, MX1, IFI27, OAS3, IFI44, Ly6E, EPISTI1, STAT1). Interestingly, these genes matched highly up-regulated genes described in the microarray analysis of tissue from synovial biopsies of patients with systemic lupus erythematosus [44]. In addition, the three genes that showed the strongest up-regulation in response to mCRP (IFI44L, MX1 and OAS2) were also found to be the most up-regulated genes in peripheral blood mononuclear cells (PBMCs) of paediatric patients with SLE [4]. Importantly, patients with SLE are more prone to the development of atherosclerosis [57] and especially women with SLE and coronary artery disease (CAD) have a poor outcome after percutaneous coronary intervention (PCI) [39]. Interferon- $\alpha$ (measured via expression of the interferon- $\alpha$ responsive genes IFI44 and MX1) has been linked to abnormal vascular repair caused by EPC dysfunction in patients with SLE thereby generating the hypothesis that interferon- $\alpha$ triggered EPC dysfunction is involved in the accelerated atherosclerosis in patients with SLE [11, 30]. This is supported by the observation that increased expression of MX1 in PBMCs of SLE patients and elevated levels of pCRP are independently associated with EPC dysfunction [37]. Furthermore, impaired function of EPCs was accompanied by increased expression of MX1 in an animal model of SLE [60]. Finally, auto-antibodies against mCRP have been described in serum from patients with active SLE [59], which generates the hypothesis that elevated mCRP levels lead to interferon- $\alpha$-mediated impairment of EPCs in patients with SLE, thereby impairing vascular repair and accelerating the development of atherosclerosis. Of note, our data do not directly demonstrate a pro-atherosclerotic effect of mCRP. However, for interferon- $\alpha$ and $\beta$, such a direct pro-atherosclerotic effect has very recently been demonstrated in mouse models of atherosclerosis [21, 43]. Most interestingly, up-regulation of MX1, OAS1, OAS2 and IFIT3 mRNA in ruptured atherosclerotic plaques in human carotid arteries has been found [21].

By confirming the fundamentally different pathological functions of mCRP and pCRP, our findings may help to explain the clinical situation in vivo. The positive impact of pCRP on endothelial colony forming capacity of EPCs observed by us has also been described in healthy volunteers [9]. Under inflammatory conditions, such as atherosclerosis, pCRP is dissociated to mCRP [15] and thus exerts substantially different functions, potentially fuelling the inflammatory response, as suggested by the results of our whole-genome gene expression analysis that suggests pro-inflammatory properties for mCRP. The localised dissociation of pCRP to mCRP in inflammation could 

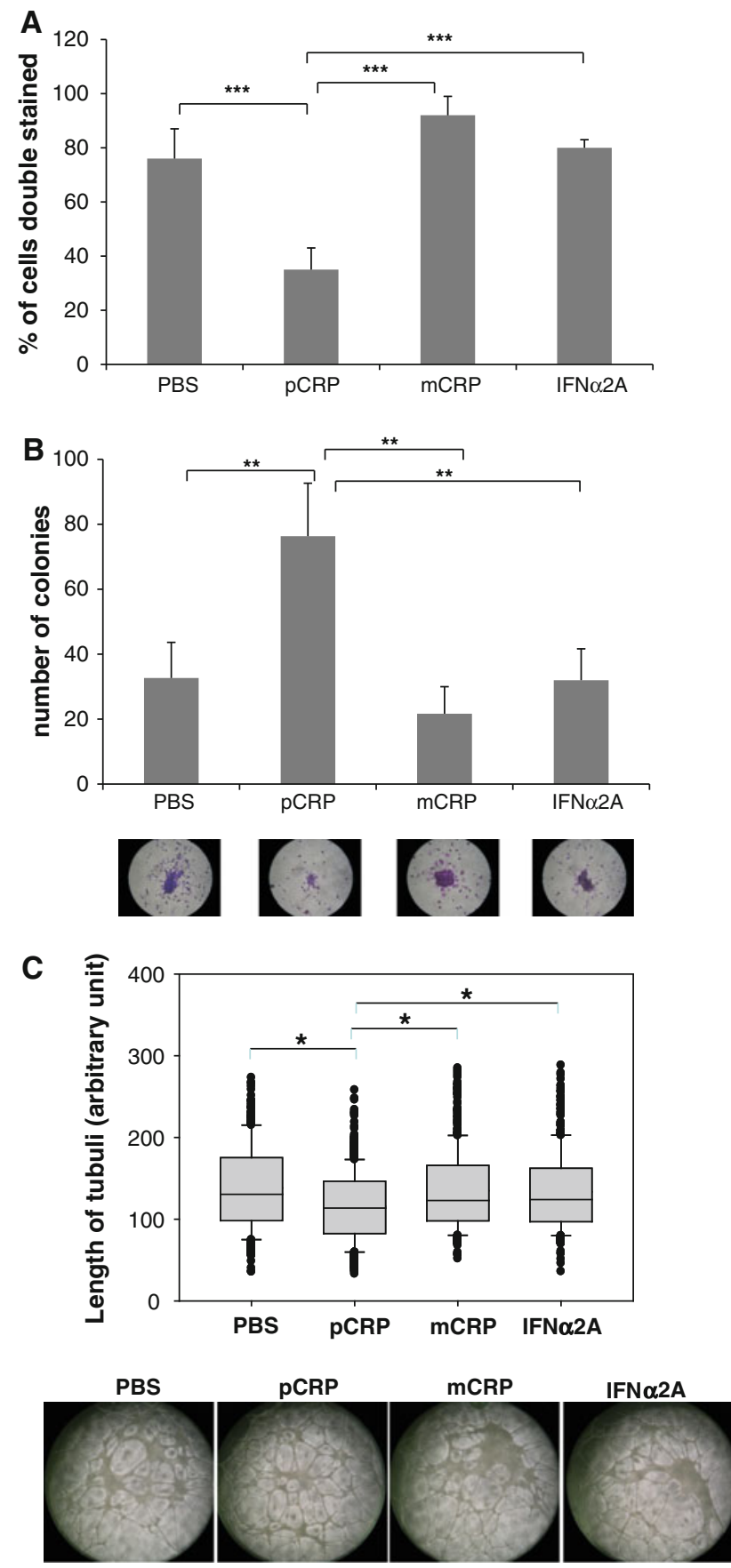

potentially mediate the negative biological effect on EPC numbers and function observed in patients with atherosclerosis $[55,67,68]$.

Our study focussed on the in vitro effects of two isoforms of CRP on cord blood-derived EPCs to explore the functional, phenotypical and gene expression profiles of monomeric and pentameric CRP towards a rare cell population with potent pro-angiogenic capabilities involved in the natural repair of vascular damage. A limitation of our study is that the results obtained in our in vitro system
4 Fig. 7 The effect of mCRP (1 mg/ml), pCRP $(5 \mathrm{mg} / \mathrm{ml})$ or IFNa2A $(1 \mathrm{ng} / \mathrm{ml})$ on phenotype and function of EPCs. a Binding of ulex lectin and uptake of acetylated LDL after $72 \mathrm{~h}$ of culture of EPCs in the presence or absence of pCRP, mCRP and IFNa2A. The bar graph shows the percentage of cells double positive for binding of ulex lectin and uptake of acetylated LDL as compared to the total number of cells in three random optical fields (20× magnification). Mean and SD of $n=3$. The statistical significance was determined by one-way ANOVA with Tukey's post hoc test, ${ }^{* * *} p<0.001$. b The bar graph shows the number of colony forming units (CFU-Hills) visualised by Giemsa staining, formed by EPCs that had been cultured in the presence of pCRP, mCRP or IFNalpha2 for $72 \mathrm{~h}$ (mean and SD of three individual donors, $n=3$ ). The statistical significance was determined by one-way ANOVA with Tukey's post hoc test, ${ }^{* *} p<0.01$. $\mathrm{c}$ The box plot shows the lengths of the tubuli formed in a co-culture of HUVECs and EPCs $(n=3)$ in an endothelial tube formation assay. The EPCs had been cultured in the presence of pCRP, mCRP or IFNa2A for $72 \mathrm{~h}$ prior to the assay. The photomicrographs were taken when a clear tubuli network was observed after $16 \mathrm{~h}$ of incubation. The statistical significance was determined by ANOVA on ranks with Dunn's post hoc test, $* p<0.05$

cannot directly be translated into in vivo situation where a more complex system of different vascular cells acts in concert to maintain the vascular integrity, and each cell type may have a different response to the two isoforms of CRP. Furthermore, the use of cord blood-derived cells may bear the risk of a differential response in gene expression in comparison to adult EPCs. However, most of the functional properties of cord blood-derived EPCs resemble those of EPCs derived from adult donors, and EPCs derived from both young and old donors have successfully been used in the past to treat cardiovascular disease in animal models and human subjects $[25,46,54,70]$. Interestingly, a recent report describes a weaker specific interferon- $\alpha$-mediated immune response in cord blood-derived mononuclear cells as compared to mononuclear cells from adult donors [65]. Therefore, our gene expression analysis could also underestimate the pro-inflammatory effects of mCRP.

In conclusion, we provide evidence for a differential, highly opposing effect of monomeric and pentameric C-reactive protein on human umbilical cord blood-derived EPCs. Monomeric CRP induced the up-regulation of proinflammatory, interferon-responsive genes in EPCs, whereas pentameric CRP exhibited a primarily noninflammatory gene response. These data support the concept that localised mCRP generation thus provides a means to locally regulate EPC function in vascular homoeostasis.

Acknowledgments This work has been supported by the National Health and Medical Research Council (NHMRC) of Australia (Peter $\mathrm{K}$ ), the Australian Research Council (future fellowship, Peter K), the German Research Foundation (AH 185/1-1, Ahrens I), the Henning and Johan Throne-Holst's Foundation (Domeij H) and the German Academic Exchange Service DAAD (D/10/47670, Albrecht M). Dr. Martha Lappas is the recipient of an NHMRC RD Wright Fellowship (Grant No. 454777). The authors gratefully acknowledge the 
skilful technical assistance of Ruusu-Maria Merivirta, in the stem cell culture; the assistance of the Clinical Research Midwives Gabrielle Fleming, Astrid Tiefholz and Anne Beeston; and the Obstetrics and Midwifery staff of the Mercy Hospital for Women for their cooperation.

\section{References}

1. Ahrens I, Domeij H, Topcic D, Mirivirta R, Bode C, Lappas M, Peter K (2010) Successful in vitro expansion and differentiation of cord blood derived CD34+ cells into functionally active endothelial progenitor cells. Eur Heart J 31:279-587 (P2341). doi:10.1093/eurheartj/ehq288

2. Albert MA, Glynn RJ, Ridker PM (2003) Plasma concentration of C-reactive protein and the calculated Framingham Coronary Heart Disease Risk Score. Circulation 108:161-165. doi: 10.1161/01.CIR.0000080289.72166.CF

3. Asahara T, Murohara T, Sullivan A, Silver M, van der Zee R, Li T, Witzenbichler B, Schatteman G, Isner JM (1997) Isolation of putative progenitor endothelial cells for angiogenesis. Science 275:964-967. doi:10.1126/science.275.5302.964

4. Bennett L, Palucka AK, Arce E, Cantrell V, Borvak J, Banchereau J, Pascual V (2003) Interferon and granulopoiesis signatures in systemic lupus erythematosus blood. J Exp Med 197:711-723. doi:10.1084/jem.20021553

5. Blaschke F, Bruemmer D, Yin F, Takata Y, Wang W, Fishbein MC, Okura T, Higaki J, Graf K, Fleck E, Hsueh WA, Law RE (2004) C-reactive protein induces apoptosis in human coronary vascular smooth muscle cells. Circulation 110:579-587. doi: 10.1161/01.CIR.0000136999.77584.A2

6. Bowman TV, Merchant AA, Goodell MA (2007) Molecular profiling of hematopoietic stem cells. Methods Mol Med 134:1-16. doi:10.1007/978-1-59745-223-6_1

7. Chen J, Huang L, Song M, Yu S, Gao P, Jing J (2009) C-reactive protein upregulates receptor for advanced glycation end products expression and alters antioxidant defenses in rat endothelial progenitor cells. J Cardiovasc Pharmacol 53:359-367. doi: 10.1097/FJC.0b013e31819b5438

8. Choi JH, Kim KL, Huh W, Kim B, Byun J, Suh W, Sung J, Jeon ES, Oh HY, Kim DK (2004) Decreased number and impaired angiogenic function of endothelial progenitor cells in patients with chronic renal failure. Arterioscler Thromb Vasc Biol 24:1246-1252. doi:10.1161/01.ATV.0000133488.56221.4a

9. Ciulla MM, Giorgetti A, Silvestris I, Cortiana M, Montelatici E, Paliotti R, Annoni GA, Fiore AV, Giordano R, De Marco F, Magrini F, Rebulla P, Cortelezzi A, Lazzari L (2006) Endothelial colony forming capacity is related to C-reactive protein levels in healthy subjects. Curr Neurovasc Res 3:99-106. doi: $10.2174 / 156720206776875876$

10. Coutts M, Cui K, Davis KL, Keutzer JC, Sytkowski AJ (1999) Regulated expression and functional role of the transcription factor CHOP (GADD153) in erythroid growth and differentiation. Blood 93:3369-3378

11. Denny MF, Thacker S, Mehta H, Somers EC, Dodick T, Barrat FJ, McCune WJ, Kaplan MJ (2007) Interferon-alpha promotes abnormal vasculogenesis in lupus: a potential pathway for premature atherosclerosis. Blood 110:2907-2915. doi:10.1182/blood-2007-05-089086

12. Di Nardo A, Kramvis I, Cho N, Sadowski A, Meikle L, Kwiatkowski DJ, Sahin M (2009) Tuberous sclerosis complex activity is required to control neuronal stress responses in an mTORdependent manner. J Neurosci 29(18):5926-5937. doi: 10.1523/JNEUROSCI.0778-09.2009
13. Dimmeler S (2010) Regulation of bone marrow-derived vascular progenitor cell mobilization and maintenance. Arterioscler Thromb Vasc Biol 30:1088-1093. doi:10.1161/ATVBAHA. 109.191668

14. Eisen MB, Spellman PT, Brown PO, Botstein D (1998) Cluster analysis and display of genome-wide expression patterns. Proc Natl Acad Sci USA 95:14863-14868. doi:10.1073/pnas.96. 19.10943-c

15. Eisenhardt SU, Habersberger J, Murphy A, Chen YC, Woollard $\mathrm{KJ}$, Bassler N, Qian $\mathrm{H}$, von Zur Muhlen C, Hagemeyer CE, Ahrens I, Chin-Dusting J, Bobik A, Peter K (2009) Dissociation of pentameric to monomeric C-reactive protein on activated platelets localizes inflammation to atherosclerotic plaques. Circ Res 105:128-137. doi:10.1161/CIRCRESAHA.108.190611

16. Eisenhardt SU, Habersberger J, Oliva K, Lancaster GI, Ayhan M, Woollard KJ, Bannasch H, Rice GE, Peter K (2011) A proteomic analysis of C-reactive protein stimulated THP-1 monocytes. Proteome Sci 9:1. doi:10.1186/1477-5956-9-1

17. Eisenhardt SU, Habersberger J, Peter K (2009) Monomeric C-reactive protein generation on activated platelets: the missing link between inflammation and atherothrombotic risk. Trends Cardiovasc Med 19:232-237. doi:10.1016/j.tcm.2010.02.002

18. Friedrich EB, Werner C, Walenta K, Bohm M, Scheller B (2009) Role of extracellular signal-regulated kinase for endothelial progenitor cell dysfunction in coronary artery disease. Basic Res Cardiol 104:613-620. doi:10.1007/s00395-009-0022-6

19. Fujii H, Li SH, Szmitko PE, Fedak PW, Verma S (2006) C-reactive protein alters antioxidant defenses and promotes apoptosis in endothelial progenitor cells. Arterioscler Thromb Vasc Biol 26:2476-2482. doi:10.1161/01.ATV.00002 42794.65541.02

20. George J, Goldstein E, Abashidze S, Deutsch V, Shmilovich H, Finkelstein A, Herz I, Miller H, Keren G (2004) Circulating endothelial progenitor cells in patients with unstable angina: association with systemic inflammation. Eur Heart $\mathrm{J}$ 25:1003-1008. doi:10.1016/j.ehj.2004.03.026

21. Goossens P, Gijbels MJ, Zernecke A, Eijgelaar W, Vergouwe MN, van der Made I, Vanderlocht J, Beckers L, Buurman WA, Daemen MJ, Kalinke U, Weber C, Lutgens E, de Winther MP (2010) Myeloid type I interferon signaling promotes atherosclerosis by stimulating macrophage recruitment to lesions. Cell Metab 12:142-153. doi:10.1016/j.cmet.2010.06.008

22. Hahne F, Mehrle A, Arlt D, Poustka A, Wiemann S, Beissbarth T (2008) Extending pathways based on gene lists using InterPro domain signatures. BMC Bioinformatics 9:3. doi:10.1186/ 1471-2105-9-3

23. He LP, Tang XY, Ling WH, Chen WQ, Chen YM (2010) Early $\mathrm{C}$-reactive protein in the prediction of long-term outcomes after acute coronary syndromes: a meta-analysis of longitudinal studies. Heart 96:339-346. doi:10.1136/hrt.2009.174912

24. Hirschi KK, Ingram DA, Yoder MC (2008) Assessing identity, phenotype, and fate of endothelial progenitor cells. Arterioscler Thromb Vasc Biol 28:1584-1595. doi:10.1161/ATVBAHA. 107.155960

25. Hu CH, Li ZM, Du ZM, Zhang AX, Rana JS, Liu DH, Yang DY, Wu GF (2010) Expanded human cord blood-derived endothelial progenitor cells salvage infarcted myocardium in rats with acute myocardial infarction. Clin Exp Pharmacol Physiol 37:551-556. doi:10.1111/j.1440-1681.2010.05347.x

26. Huo Y, Schober A, Forlow SB, Smith DF, Hyman MC, Jung S, Littman DR, Weber C, Ley K (2003) Circulating activated platelets exacerbate atherosclerosis in mice deficient in apolipoprotein E. Nat Med 9:61-67. doi:10.1038/nm810

27. Irizarry RA, Hobbs B, Collin F, Beazer-Barclay YD, Antonellis KJ, Scherf U, Speed TP (2003) Exploration, normalization, and 
summaries of high density oligonucleotide array probe level data. Biostatistics 4:249-264. doi:10.1093/biostatistics/4.2.249

28. Ji SR, Wu Y, Zhu L, Potempa LA, Sheng FL, Lu W, Zhao J (2007) Cell membranes and liposomes dissociate C-reactive protein (CRP) to form a new, biologically active structural intermediate: $\mathrm{mCRP}(\mathrm{m})$. FASEB J 21:284-294. doi: 10.1096/fj.06-6722com

29. Jujo K, Ii M, Losordo DW (2008) Endothelial progenitor cells in neovascularization of infarcted myocardium. J Mol Cell Cardiol 45:530-544. doi:10.1016/j.yjmcc.2008.08.003

30. Kaplan MJ (2009) Premature vascular damage in systemic lupus erythematosus. Autoimmunity 42:580-586. doi:10.1080/08916 930903002479

31. Kaur S, Kumar TR, Uruno A, Sugawara A, Jayakumar K, Kartha CC (2009) Genetic engineering with endothelial nitric oxide synthase improves functional properties of endothelial progenitor cells from patients with coronary artery disease: an in vitro study. Basic Res Cardiol 104:739-749. doi:10.1007/s00395-009-0039-x

32. Khreiss T, Jozsef L, Hossain S, Chan JS, Potempa LA, Filep JG (2002) Loss of pentameric symmetry of C-reactive protein is associated with delayed apoptosis of human neutrophils. J Biol Chem 277:40775-40781. doi:10.1074/jbc.M205378200

33. Khreiss T, Jozsef L, Potempa LA, Filep JG (2004) Conformational rearrangement in C-reactive protein is required for proinflammatory actions on human endothelial cells. Circulation 109:2016-2022. doi:10.1161/01.CIR.0000125527.41598.68

34. Khreiss T, Jozsef L, Potempa LA, Filep JG (2004) Opposing effects of C-reactive protein isoforms on shear-induced neutrophil-platelet adhesion and neutrophil aggregation in whole blood. Circulation 110:2713-2720. doi:10.1161/01.CIR.0000 146846.00816.DD

35. Khreiss T, Jozsef L, Potempa LA, Filep JG (2005) Loss of pentameric symmetry in C-reactive protein induces interleukin-8 secretion through peroxynitrite signaling in human neutrophils. Circ Res 97:690-697. doi:10.1161/01.RES.0000183881.117 39. CB

36. LeCouter J, Zlot C, Tejada M, Peale F, Ferrara N (2004) Bv8 and endocrine gland-derived vascular endothelial growth factor stimulate hematopoiesis and hematopoietic cell mobilization. Proc Natl Acad Sci USA 101:16813-16818. doi:10.1073/pnas. 0407697101

37. Lee PY, Li Y, Richards HB, Chan FS, Zhuang H, Narain S, Butfiloski EJ, Sobel ES, Reeves WH, Segal MS (2007) Type I interferon as a novel risk factor for endothelial progenitor cell depletion and endothelial dysfunction in systemic lupus erythematosus. Arthritis Rheum 56:3759-3769. doi:10.1002/art.23035

38. Liu C, Wang S, Deb A, Nath KA, Katusic ZS, McConnell JP, Caplice NM (2005) Proapoptotic, antimigratory, antiproliferative, and antiangiogenic effects of commercial C-reactive protein on various human endothelial cell types in vitro: implications of contaminating presence of sodium azide in commercial preparation. Circ Res 97:135-143. doi:10.1161/01.RES.0000174 612.90094.fd

39. Maksimowicz-McKinnon K, Selzer F, Manzi S, Kip KE, Mulukutla SR, Marroquin OC, Smitherman TC, Kuller LH, Williams DO, Wasko MC (2008) Poor 1-year outcomes after percutaneous coronary interventions in systemic lupus erythematosus: report from the National Heart, Lung, and Blood Institute Dynamic Registry. Circ Cardiovasc Interv 1:201-208. doi:10.1161/CIRCI NTERVENTIONS.108.788745

40. Molins B, Pena E, Vilahur G, Mendieta C, Slevin M, Badimon L (2008) C-reactive protein isoforms differ in their effects on thrombus growth. Arterioscler Thromb Vasc Biol 28:2239-2246. doi:10.1161/ATVBAHA.108.174359

41. Mootha VK, Lindgren CM, Eriksson KF, Subramanian A, Sihag S, Lehar J, Puigserver P, Carlsson E, Ridderstrale M, Laurila E,
Houstis N, Daly MJ, Patterson N, Mesirov JP, Golub TR, Tamayo P, Spiegelman B, Lander ES, Hirschhorn JN, Altshuler D, Groop LC (2003) PGC-1alpha-responsive genes involved in oxidative phosphorylation are coordinately downregulated in human diabetes. Nat Genet 34:267-273. doi:10.1038/ng1180

42. Namba T, Tanaka K, Ito Y, Ishihara T, Hoshino T, Gotoh T, Endo M, Sato K, Mizushima T (2009) Positive role of CCAAT/ enhancer-binding protein homologous protein, a transcription factor involved in the endoplasmic reticulum stress response in the development of colitis. Am J Pathol 174:1786-1798. doi: 10.2353/ajpath.2009.080864

43. Noels H, Weber C (2011) Catching up with important players in atherosclerosis: type I interferons and neutrophils. Curr Opin Lipidol 22:144-145. doi:10.1097/MOL.0b013e328344780b

44. Nzeusseu Toukap A, Galant C, Theate I, Maudoux AL, Lories RJ, Houssiau FA, Lauwerys BR (2007) Identification of distinct gene expression profiles in the synovium of patients with systemic lupus erythematosus. Arthritis Rheum 56:1579-1588. doi: 10.1002/art.22578

45. Orlandi A, Chavakis E, Seeger F, Tjwa M, Zeiher AM, Dimmeler S (2010) Long-term diabetes impairs repopulation of hematopoietic progenitor cells and dysregulates the cytokine expression in the bone marrow microenvironment in mice. Basic Res Cardiol 105:703-712. doi:10.1007/s00395-010-0109-0

46. Ott I, Keller U, Knoedler M, Gotze KS, Doss K, Fischer P, Urlbauer K, Debus G, von Bubnoff N, Rudelius M, Schomig A, Peschel C, Oostendorp RA (2005) Endothelial-like cells expanded from CD34+ blood cells improve left ventricular function after experimental myocardial infarction. FASEB J 19:992-994. doi:10.1096/fj.04-3219fje

47. Padfield GJ, Tura O, Haeck ML, Short A, Freyer E, Barclay GR, Newby DE, Mills NL (2010) Circulating endothelial progenitor cells are not affected by acute systemic inflammation. Am J Physiol Heart Circ Physiol 298:H2054-H2061. doi: 10.1152/ajpheart.00921.2009

48. Poss J, Werner C, Lorenz D, Gensch C, Bohm M, Laufs U (2010) The renin inhibitor aliskiren upregulates pro-angiogenic cells and reduces atherogenesis in mice. Basic Res Cardiol 105:725-735. doi:10.1007/s00395-010-0120-5

49. Raponi M, Belly RT, Karp JE, Lancet JE, Atkins D, Wang Y (2004) Microarray analysis reveals genetic pathways modulated by tipifarnib in acute myeloid leukemia. BMC Cancer 4:56. doi: 10.1186/1471-2407-4-56

50. Richardson MR, Yoder MC (2011) Endothelial progenitor cells: quo vadis? J Mol Cell Cardiol 50:266-272. doi:10.1016/j. yjmcc.2010.07.009

51. Ridker PM, Hennekens CH, Buring JE, Rifai N (2000) C-reactive protein and other markers of inflammation in the prediction of cardiovascular disease in women. N Engl J Med 342:836-843

52. Ryu J, Lee CW, Shin JA, Park CS, Kim JJ, Park SJ, Han KH (2007) FcgammaRIIa mediates C-reactive protein-induced inflammatory responses of human vascular smooth muscle cells by activating NADPH oxidase 4. Cardiovasc Res 75:555-565. doi:10.1016/j.cardiores.2007.04.027

53. Sandstedt J, Jonsson M, Lindahl A, Jeppsson A, Asp J (2010) C-kit+ CD45- cells found in the adult human heart represent a population of endothelial progenitor cells. Basic Res Cardiol 105:545-556. doi:10.1007/s00395-010-0088-1

54. Schachinger V, Erbs S, Elsasser A, Haberbosch W, Hambrecht R, Holschermann H, Yu J, Corti R, Mathey DG, Hamm CW, Suselbeck T, Assmus B, Tonn T, Dimmeler S, Zeiher AM (2006) Intracoronary bone marrow-derived progenitor cells in acute myocardial infarction. N Engl J Med 355:1210-1221. doi: 10.1056/NEJMoa060186

55. Schmidt-Lucke C, Rossig L, Fichtlscherer S, Vasa M, Britten M, Kamper U, Dimmeler S, Zeiher AM (2005) Reduced number of 
circulating endothelial progenitor cells predicts future cardiovascular events: proof of concept for the clinical importance of endogenous vascular repair. Circulation 111:2981-2987. doi: 10.1161/CIRCULATIONAHA.104.504340

56. Schwedler SB, Filep JG, Galle J, Wanner C, Potempa LA (2006) C-reactive protein: a family of proteins to regulate cardiovascular function. Am J Kidney Dis 47:212-222. doi:10.1053/j.ajkd. 2005.10.028

57. Sherer Y, Zinger H, Shoenfeld Y (2010) Atherosclerosis in systemic lupus erythematosus. Autoimmunity 43:98-102. doi: 10.3109/08916930903374527

58. Steinmetz M, Nickenig G, Werner N (2011) Endothelial-regenerating cells: an expanding universe. Hypertension 55:593-599. doi:10.1161/HYPERTENSIONAHA.109.134213

59. Tan Y, Yu F, Yang H, Chen M, Fang Q, Zhao MH (2008) Autoantibodies against monomeric $\mathrm{C}$-reactive protein in sera from patients with lupus nephritis are associated with disease activity and renal tubulointerstitial lesions. Hum Immunol 69:840-844. doi:10.1016/j.humimm.2008.09.006

60. Thacker SG, Duquaine D, Park J, Kaplan MJ (2010) Lupus-prone New Zealand black/New Zealand white F1 mice display endothelial dysfunction and abnormal phenotype and function of endothelial progenitor cells. Lupus 19:288-299. doi: 10.1177/0961203309353773

61. Timmermans F, Plum J, Yoder MC, Ingram DA, Vandekerckhove B, Case J (2009) Endothelial progenitor cells: identity defined? J Cell Mol Med 13:87-102. doi:10.1111/j.15824934.2008.00598.x

62. Tsuzuki M (2009) Bone marrow-derived cells are not involved in reendothelialized endothelium as endothelial cells after simple endothelial denudation in mice. Basic Res Cardiol 104:601-611. doi:10.1007/s00395-009-0021-7

63. Van Craenenbroeck EM, Hoymans VY, Beckers PJ, Possemiers NM, Wuyts K, Paelinck BP, Vrints CJ, Conraads VM (2010) Exercise training improves function of circulating angiogenic cells in patients with chronic heart failure. Basic Res Cardiol 105:665-676. doi:10.1007/s00395-010-0105-4

64. Verma S, Kuliszewski MA, Li SH, Szmitko PE, Zucco L, Wang CH, Badiwala MV, Mickle DA, Weisel RD, Fedak PW, Stewart
DJ, Kutryk MJ (2004) C-reactive protein attenuates endothelial progenitor cell survival, differentiation, and function: further evidence of a mechanistic link between C-reactive protein and cardiovascular disease. Circulation 109:2058-2067. doi: 10.1161/01.CIR.0000127577.63323.24

65. Vosters O, Lombard C, Andre F, Sana G, Sokal EM, Smets F (2010) The interferon-alpha and interleukin-10 responses in neonates differ from adults, and their production remains partial throughout the first 18 months of life. Clin Exp Immunol 162:494-499. doi:10.1111/j.1365-2249.2010.04267.x

66. Walenta KL, Bettink S, Bohm M, Friedrich EB (2010) Differential chemokine receptor expression regulates functional specialization of endothelial progenitor cell subpopulations. Basic Res Cardiol 106:299-305. doi:10.1007/s00395-010-0142-z

67. Werner N, Kosiol S, Schiegl T, Ahlers P, Walenta K, Link A, Bohm M, Nickenig G (2005) Circulating endothelial progenitor cells and cardiovascular outcomes. N Engl J Med 353:999-1007. doi:10.1056/NEJMoa043814

68. Werner N, Nickenig G (2006) Clinical and therapeutical implications of EPC biology in atherosclerosis. J Cell Mol Med 10:318-332. doi:10.1111/j.1582-4934.2006.tb00402.x

69. Yoder MC (2009) Defining human endothelial progenitor cells. J Thromb Haemost 7(Suppl 1):49-52. doi:10.1111/j.1538-7836. 2009.03407.x

70. Yu Y, Gao Y, Qin J, Kuang CY, Song MB, Yu SY, Cui B, Chen JF, Huang L (2010) CCN1 promotes the differentiation of endothelial progenitor cells and reendothelialization in the early phase after vascular injury. Basic Res Cardiol 105:713-724. doi:10.1007/s00395-010-0117-0

71. Zimmermann O, Bienek-Ziolkowski M, Wolf B, Vetter M, Baur R, Mailander V, Hombach V, Torzewski J (2009) Myocardial inflammation and non-ischaemic heart failure: is there a role for C-reactive protein? Basic Res Cardiol 104:591-599. doi:10.1007/s00395-009-0026-2

72. Zouki C, Haas B, Chan JS, Potempa LA, Filep JG (2001) Loss of pentameric symmetry of C-reactive protein is associated with promotion of neutrophil-endothelial cell adhesion. J Immunol 167:5355-5361 